\title{
INTERAÇÕES ENTRE LEVEDURAS E BACTÉRIAS DURANTE A FERMENTAÇÃO ALCOÓLICA
}

\author{
RODRIGO SETEM CARVALHO \\ Biólogo
}

Orientador: Prof. Dr. Luiz Carlos Basso

\author{
Dissertação apresentada à Escola Superior de \\ Agricultura "Luiz de Queiroz", Universidade \\ de São Paulo, para obtenção do título de \\ Mestre em Ciências, Área de Concentração: \\ Ciência e Tecnologia de Alimentos \\ PIRAC ICABA \\ Estado de São Paulo - Brasil \\ Novembro - 2001
}




\section{ERRATA}

Rodrigo Setem Carvalho. Interações entre leveduras e bactérias durante a fermentação alcoólica.

\begin{tabular}{|c|c|c|c|c|}
\hline p. & item & linha & onde se lê & leia-se \\
\hline vi & sumário & $\operatorname{dez}$ & ...no vinho de... & $\begin{array}{l}\text {...em meios obtidos dos } \\
\text { vinhos de... }\end{array}$ \\
\hline xii & resumo & três & ...acima... & ...anteriormente... \\
\hline xii & resumo & oito & ...L. fermentum. & ...L. fermentum (CCT 1407). \\
\hline xiii & summary & um & ...ALCOOLIC... & ...ALCOHOLIC... \\
\hline 2 & 1 & nove & ...linhagens... & ...linhagens de leveduras... \\
\hline 10 & 2.1 & dezessete & ...contaminante e... & $\begin{array}{l}\text {...contaminante dos processos } \\
\text { fermentativos da indústria } \\
\text { sucroalcoleira e... }\end{array}$ \\
\hline 13 & 2.2 & dois & ...crescimento. & ...crescimento... \\
\hline 20 & 3.1 .1 & oito & ...figura abaixo. (Figura 1) & ...Figura 1. \\
\hline 21 & 3.1 .1 & oito & $\begin{array}{l}\text {...introdução no tubo de óleo } \\
\text { mineral líquido esterilizado... }\end{array}$ & $\begin{array}{l}\text {...introdução de óleo mineral } \\
\text { líquido esterilizado nesses } \\
\text { tubos de ensaio... }\end{array}$ \\
\hline 21 & 3.1 .2 & doze & $\begin{array}{l}\text {...temperatura ambiente }(28 \pm \\
\left.1^{\circ} \mathrm{C}\right) \text { por... }\end{array}$ & $\begin{array}{l}\text {...temperatura de } 28 \pm 1^{\circ} \mathrm{C} \\
\text { por... }\end{array}$ \\
\hline 24 & 3.1 .5 & nove & ...ajustar os tubos... & $\begin{array}{l}\text {...ajustar o volume dos } \\
\text { tubos... }\end{array}$ \\
\hline 24 & 3.1 .6 & vinte e dois & $\left.\ldots n^{\circ} 54\right)$ & $\begin{array}{l}\text {... } \mathrm{n}^{\circ} 54 \text {, que corresponde à um } \\
\text { comprimento de onda de } \\
\text { aproximadamente } 540 \mathrm{~nm} \text { ). }\end{array}$ \\
\hline 25 & 3.2 .2 & $\operatorname{dez}$ & ...linolêico... & ...linoleico... \\
\hline 29 & 3.3 .1 & quatro & TUDO & $10,5 \mathrm{~mL}$ \\
\hline 31 & 3.3 .3 & quatro & $\begin{array}{l}\text { A viabilidade da levedura, } \\
\text { assim como os teores... }\end{array}$ & Os teores... \\
\hline 34 & 3.4 .6 & dezessete & $\begin{array}{l}\text {..1989), de açúcares residuais } \\
\text { (AR) e glicerol. }\end{array}$ & ...1989). \\
\hline
\end{tabular}


Dados Internacionais de Catalogação na Publicação (CIP) DIVISÃO DE BIBLIOTECA E DOCUMENTAÇÃO - ESALQ/USP

\section{Carvalho, Rodrigo Setem}

Interaçōes entre leveduras e bactérias durante a fermentação alcoólica / Rodrigo Setem Carvalho. - - Piracicaba, 2001.

$$
74 \text { p. : il. }
$$

Dissertação (mestrado) - Escola Superior de Agricultura Luiz de Queiroz, 2001. Bibliografia.

1. Fermentação alcoólica 2. Invertase 3. Leveduras 4. Relação levedura-bactérias . I. Título

CDD 589.90524

Wermitida a copia total ou parcial deste documento, desde que citada a fonte - O autor" 
Aos meus pais, Júlio e Inês, e à minha irmã, Juliana Ofereço

"O Senhor te guiará continuamente..." (Isaías, 58:11)

À Deus Agradeço 


\section{AGRADECIMENTOS}

Ao Prof. Dr. Luiz Carlos Basso, pela orientação e confiança durante a realização deste trabalho.

À Escola Superior de Agricultura "Luiz de Queiróz"/USP pela oportunidade de realização desse Curso.

Aos meus familiares, pelo apoio e compreensão.

À minha mãe pela constante ajuda e à minha irmã pelo auxílio na elaboração do summary.

Aos funcionários e amigos Luis Lucatti e Admir de Almeida Campos pela colaboração e enorme auxílio nas análises laboratoriais.

À todos os amigos do laboratório de Bioquímica da ESALQ, principalmente ao Rudimar pela troca de informações.

Ao Conselho Nacional de Desenvolvimento Científico e Tecnológico (CNPq), pela bolsa de estudos oferecida durante o curso.

À todos que, direta ou indiretamente, contribuíram para a realização desse trabalho. 


\section{SUMÁRIO}

Página

LISTA DE FIGURAS................................................................. viii

LISTA DE QUADROS ................................................................. $\quad$ x

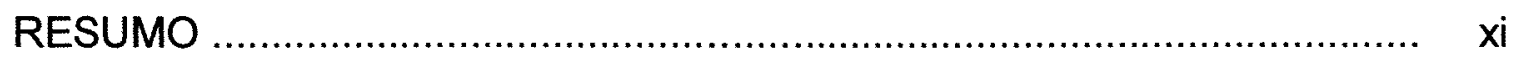

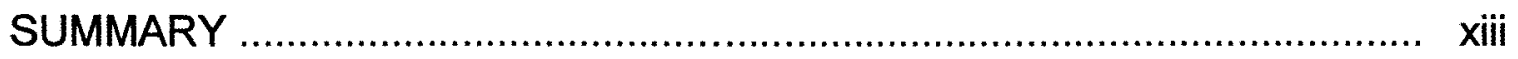

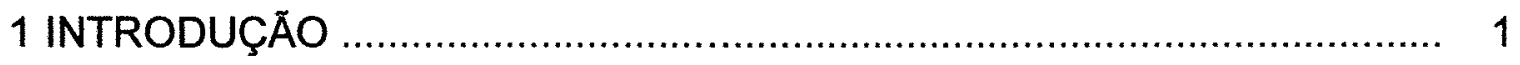

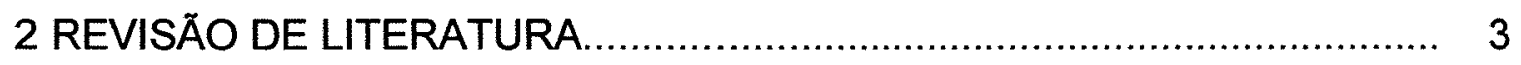

2.1 Contaminação bacteriana na indústria sucroalcoleira $\ldots \ldots \ldots \ldots \ldots \ldots \ldots \ldots \ldots . \ldots \ldots$

2.2 Lactobacillus fermentum ....................................................... 12

2.3 Aspectos do metabolismo de carboidratos de bactérias láticas ............ 13

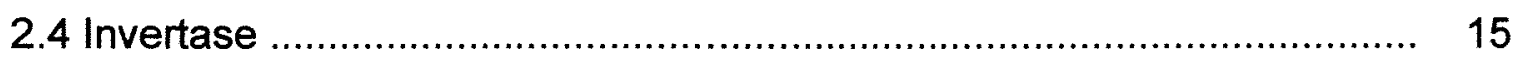

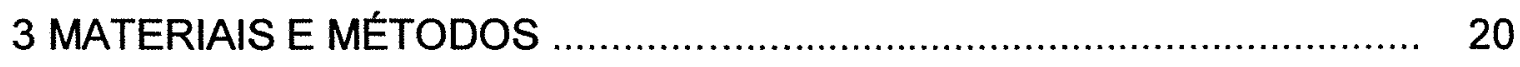

3.1 Análise do teor de invertase no vinho de diferentes leveduras ............ 20

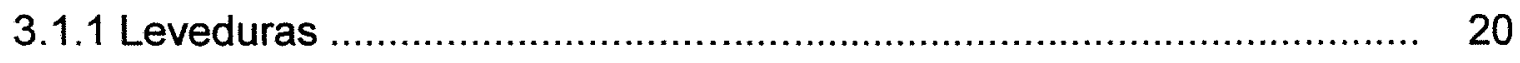

3.1.2 Multiplicação das leveduras ............................................. 21

3.1.3 Análise da invertase nos vinhos ........................................ 22

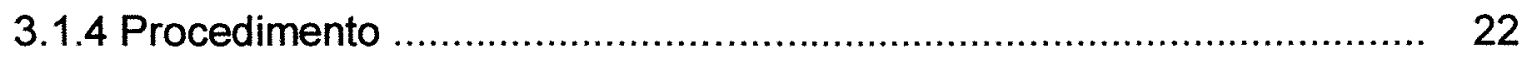

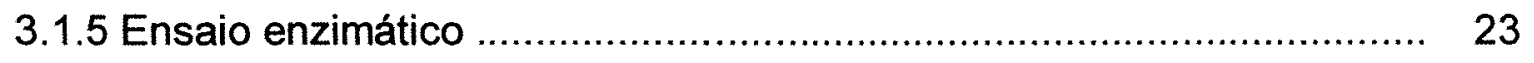


3.1.6 Reação para dosagem de açúcares redutores

3.2 Análise do teor de invertase do espaço periplasmático de diferentes leveduras 25

3.2.1 Leveduras 25

3.2.2 Multiplicação das leveduras 25

3.2.3 Análise da invertase nos vinhos 25

3.2.4 Procedimento - preparação do extrato bruto (Suco de Lebedev) ....... 26

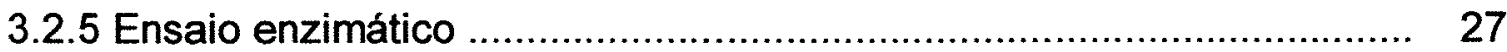

3.2.6 Reação para dosagem de açúcares redutores ................................. 27

3.3 Crescimento de lactobacilos no vinho de diferentes leveduras............... 28

3.3.1 Curva de calibração de $L$. fermentum .............................................. 28

3.3.2 Curva de crescimento de lactobacilos no vinho de diferentes

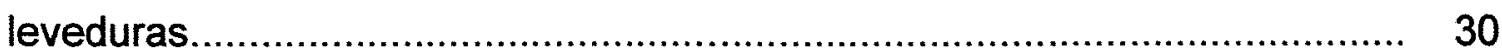

3.3.3 Meio de crescimento .................................................................. 31

3.4 Ensaio de fermentação .................................................................... 33

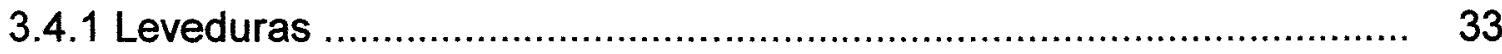

3.4.2 Multiplicação das leveduras ........................................................ 33

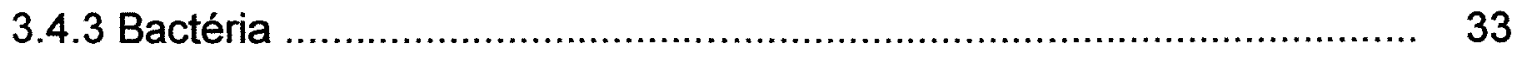

3.4.4 Multiplicação das bactérias ......................................................... 33

3.4.5 Meio de fermentação …............................................................... 33

3.4.6 Ensaio de fermentação ........................................................... 34

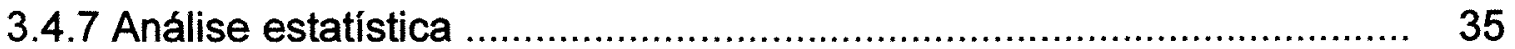

4 RESULTADOS E DISCUSSÃO _........................................................ 36 
4.1 Análise da invertase excretada no meio e do espaço periplasmático de diferentes leveduras 36

4.2 Crescimento de lactobacilos no vinho de diferentes leveduras............... 39

4.3 Ensaio de fermentação ............................................................ 42

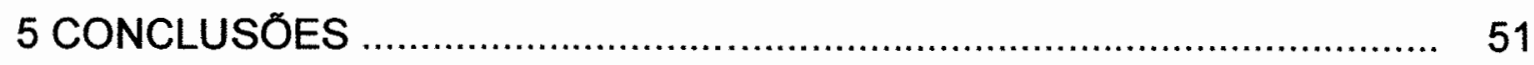

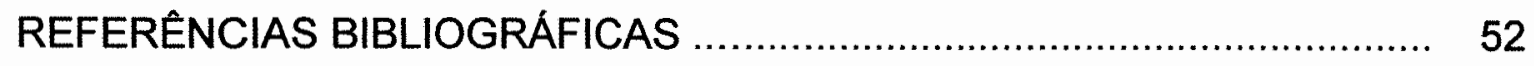

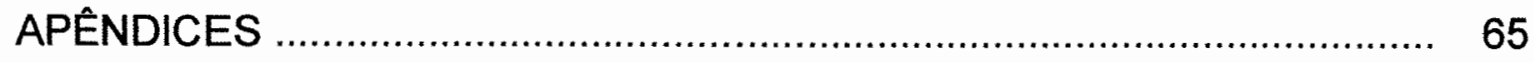




\section{LISTA DE FIGURAS}

Página

1Esquema de estocagem das leveduras ................................................... 21

2 Esquema da análise do teor de invertase no vinho de caldo de cana e de mosto misto de diferentes leveduras ..................................................... 23

3 Esquema da análise do teor de invertase no vinho de melaço e do autolisado de diferentes leveduras .................................................................. 26

4 Esquema da extração da invertase do espaço periplasmático de diferentes

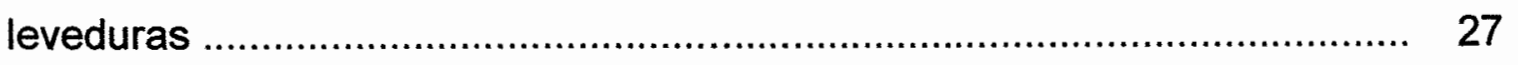

5 Esquema de estocagem das bactérias ............................................ 28

6 Esquema de multiplicação de L. fermentum ........................................... 29

7 Esquema da obtenção do vinho de diferentes leveduras utilizado para a avaliação do crescimento de $L$. fermentum ............................................. 30

8 Meios de crescimento da bactéria $L$. fermentum ............................... 31

9 Esquema de multiplicação da bactéria ................................................... 32

10 Curva de crescimento de $L$. fermentum em meios YED $(0,5 \%$ de extrato de levedura $+1 \%$ de glicose) em água (ÁGUA) e água e vinho (1:1) (AV) (a) e em água $(A G U A)$ e vinho $(V)$ (b) (primeiro experimento = vinho de melaço $A) . . \quad 40$ 
11 Curva de crescimento de $L$. fermentum em meios YED $(0,5 \%$ de extrato de levedura $+1 \%$ de glicose) em água (ÁGUA) e água e vinho (1:1) (AV) (a) e em água $(A G \cup A)$ e vinho $(V)(b)$ (segundo experimento = vinho de melaço $B) . .41$ 12 Efeitos de diferentes leveduras em co-cultura com lactobacilos ao longo de 10 ciclos fermentativos sobre o $\mathrm{pH}$ dos vinhos e viabilidade das leveduras . 43 13 Efeitos de diferentes leveduras em co-cultura com lactobacilos ao longo de 10 ciclos fermentativos sobre a contaminação bacteriana (contagem ao microscópio) e rendimento............................................................ 44 14 Efeitos de diferentes leveduras em co-cultura com lactobacilos ao longo de 10 ciclos fermentativos sobre $o$ peso do fermento e taxa de

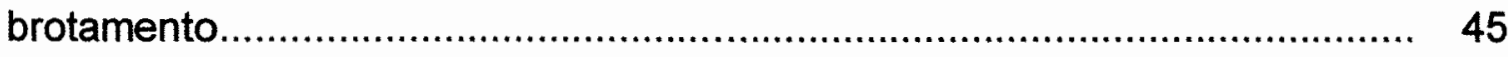
15 Efeitos de diferentes leveduras em co-cultura com lactobacilos ao longo de 10 ciclos fermentativos sobre o teor de etanol nos vinhos. 


\section{LISTA DE QUADROS}

Página

1 Atividade de invertase excretada no meio (em $\mu \mathrm{g} \mathrm{AR} \cdot \mathrm{h}^{-1} \cdot \mathrm{mg} \mathrm{lev}^{-1}$ ) de leveduras crescidas em meio de caldo de cana ....................................... 37

2 Atividade de invertase excretada no meio (em $\mu \mathrm{g} \mathrm{AR} \cdot \mathrm{h}^{-1} \cdot \mathrm{mg} \mathrm{lev}^{-1}$ ) de leveduras crescidas em mosto misto (caldo + melaço) .............................. 37

3 Primeiro experimento de determinação da atividade de invertase (em $\mu \mathrm{g} \mathrm{AR} . \mathrm{h}^{-}$ ${ }^{1} . \mathrm{mg} \mathrm{lev}^{-1}$ ) do espaço periplasmático de leveduras crescidas em meio de melaço com 6\% de ART ................................................................... 37

4 Segundo experimento (semelhante ao primeiro) de determinação da atividade

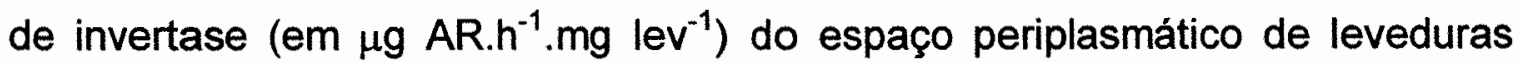
crescidas em meio de melaço com $6 \%$ de ART.

5 Contagem de bactérias através de plaqueamento em profundidade "pourplate" em meio de cultura MRS adicionado de actidiona tanto no primeiro ciclo como no vinho do sétimo ciclo fermentativo.

6 Teores celulares de trealose e glicogênio (\% na matéria seca) nas diferentes linhagens de leveduras antes do ensaio e após o $10^{\circ}$ ciclo fermentativo...... 


\title{
INTERAÇÕES ENTRE LEVEDURAS E BACTÉRIAS DURANTE A FERMENTAÇÃO ALCOÓLICA
}

\author{
Autor: RODRIGO SETEM CARVALHO \\ Orientador: Prof. Dr. LUIZ CARLOS BASSO
}

\section{RESUMO}

Na fermentação alcoólica de substratos oriundos da cana-de-açúcar (caldo e/ou melaço), a sacarose é o principal açúcar e sofre inicialmente a ação da invertase da levedura, sendo transformada em glicose e frutose. Ao que parece essa hidrólise é muito mais rápida que a metabolização das hexoses, ocorrendo acúmulo dos monossacarídeos, os quais podem exercer um estresse osmótico à levedura, bem como disponibilizar tais hexoses para o crescimento de lactobacilos contaminantes do processo fermentativo industrial. Neste trabalho foi quantificada a atividade de invertase de 5 linhagens de Saccharomyces cerevisiae (PE-2, BG-1, CAT-1, FLE e IZ-1904) todas pertencentes à coleção de leveduras do Departamento de Ciências Biológicas da ESALQ/USP. A atividade de invertase foi determinada tanto nos meios de crescimento (caldo, mosto misto e melaço) como também nas leveduras após a autólise com bicarbonato de sódio. Ambas as quantificações levaram à conclusão de que, em ordem crescente, a atividade de invertase dessas linhagens foi a seguinte: CAT-1, PE-2, BG-1, IZ-1904 e FLE. A 
segunda etapa deste trabalho consistiu em estudar a interação levedura-bactéria durante a fermentação alcoólica, buscando correlacionar a atividade de invertase com a contaminação bacteriana. Nesta etapa, foram comparadas as leveduras descritas acima, buscando melhor entender as relações tróficas entre Saccharomyces e Lactobacillus em co-cultura. Os estudos conduzidos consistiram em ensaios de fermentação com reciclos, procurando-se imitar as condições industriais e concluiu-se que, nessas condições, a atividade de invertase não exerceu influência sobre os níveis de contaminação por $L$. fermentum. 


\title{
INTERACTIONS BETWEEN YEASTS AND BACTERIA DURING ALCOOLIC FERMENTATION
}

\author{
Author: RODRIGO SETEM CARVALHO \\ Adviser: Prof. Dr. LUIZ CARLOS BASSO
}

\section{SUMMARY}

During alcoholic fermentation of sugar cane substrates (sugar cane juice and/or molasses), sucrose, the main sugar, initially is hydrolized by the action of the yeast invertase, been converted into glucose and fructose. This hydrolizis is faster than the metabolism of the resulting hexoses, occurring accumulation of the monossacharides, which can cause an osmotic stress on yeast and supply contaminant lactobacillus with hexoses during the industrial fermentation process. In the present work, the invertase activity of five Saccharomyces cerevisiae strains: (PE-2, BG-1, CAT-1, FLE and IZ1904) were quantified. The invertase activity was estimated in the media after yeast growth (cane juice and/or molasses) and also in yeast extracted with sodium bicarbonate. Both quantitations showed that, in an increasing order, the invertase activity of these strains were: CAT-1 < PE-2 < BG-1 < IZ-1904 < FLE. This work also aimed to investigate the interaction between yeast and bacteria during alcoholic fermentation, in order to verify if invertase could effect the bacterial contamination. The mencioned 
strains were subjected to fermentation with cell recycling in presence of Lactobacillus fermentum (CCT 1407), and the data showed no difference between yeast strains in relation to bacterial growth. 


\section{INTRODUÇÃO}

A agroindústria do álcool, juntamente com a do aguardente, representa um considerável gerador econômico, sendo o setor de suma importância para o país. Toda a produção de álcool e de aguardente, no Brasil, ocorre por via fermentativa, sendo fundamental portanto, o conhecimento do processo como um todo.

A fermentação etanólica é um processo microbiológico, que pode ser conduzido por diferentes microrganismos, denominados taxonomicamente como leveduras. Entre essas, o gênero Saccharomyces, representado por linhagens de Saccharomyces cerevisiae, tem se adaptado às condições industriais.

A contaminação bacteriana é um sério problema na fermentação alcoólica industrial, sendo as bactérias indesejáveis para o processo, pois levam à perdas operacionais. As contaminantes podem afetar a viabilidade da levedura, levando a quedas na produtividade e rendimento fermentativo (Novaes, 1992).

Levantamentos sobre esses contaminantes demonstram a predominância de bactérias láticas, principalmente as do gênero Lactobacillus, sendo a espécie $L$. fermentum a de maior ocorrência (Gallo e Canhos, 1991).

O comportamento das bactérias láticas em cultivo misto com leveduras tem sido pesquisado, mas permanecem dúvidas sobre o mecanismo da estimulação bacteriana. Smith et al. (1975) e Oliva-Neto e Yokoya (1996) tem atribuído essa estimulação a 
aminoácidos liberados pela autólise das leveduras. Lafon-Lafourcade et al. (1983) e Essia Ngang et al. (1992) propõe que os monossacarídeos liberados durante a hidrólise da sacarose, seriam os principais responsáveis por este fenômeno. Já King e Beelman (1986) apontam o etanol, em concentrações abaixo de $2 \%$, como estimulante ao crescimento bacteriano.

O conhecimento da natureza dessa contaminação se faz necessário para o melhoramento do processo como um todo.

\section{Objetivos}

No presente trabalho buscou-se avaliar se linhagens com diferentes atividades de invertase poderiam afetar o nível de contaminação com lactobacilos em fermentação mista. Para isso, a atividade de invertase de diferentes linhagens de leveduras foi quantificada e, então, estudou-se a interação levedura-bactéria na fermentação alcoólica caracterizando o papel da invertase como uma facilitadora ou não da contaminação bacteriana, verificando se a liberação de monossacarídeos no meio fermentativo contribui para o desenvolvimento de Lactobacillus fermentum em fermentação mista, simulando o processo industrial de produção de etanol com reciclo de células. 


\section{REVISÃO DE LITERATURA}

\subsection{Contaminação bacteriana na indústria sucroalcoleira}

O caldo de cana se constitui em ótimo substrato para o crescimento de muitos microrganismos, em função dos teores de nutrientes orgânicos e inorgânicos que apresenta, alta atividade de água e $\mathrm{pH}$ favoráveis. Assim, uma ampla e variada microbiota bacteriana encontra-se normalmente presente no mosto utilizado para a produção de álcool, como mostram os dados de inúmeros trabalhos na literatura sobre o assunto. Esses contaminantes são habitantes naturais da planta, do solo, matéria orgânica em decomposição e dos microrganismos associados às pragas e moléstias da cultura. As bactérias participam ativamente na deterioração da cana colhida, reduzindo o tempo de estocagem e introduzem no processo produtos indesejáveis do metabolismo que tanto dificultam as etapas anteriores à fermentação, como causam alterações ambientais desfavoráveis às leveduras durante a fermentação. Um rigoroso controle microbiológico do processamento, com a sistemática eliminação de contaminantes, precisa ser melhor investigado e conhecido (Gallo e Canhos, 1991; Yokoya, 1991).

Não é recente a preocupação de muitos autores com a contaminação bacteriana no processo de extração de caldo e na indústria da fermentação alcoólica, particularmente na produção de bebidas, sendo importante ressaltar os trabalhos de 
Pasteur no fim do século retrasado com cervejas e vinhos contaminados, que permitiram grande desenvolvimento da microbiologia (Boletim Técnico Copersucar, 1983).

Em um estudo realizado junto a algumas destilarias, a Copersucar (Boletim Técnico Copersucar, 1983) concluiu que:

- A água de lavagem da cana: quando o pH é mantido na faixa de 10-11, tem-se baixa contagem microbiana, mas quando o pH torna-se próximo ou inferior à neutralidade, observam-se aumentos significativos na contagem microbiana.

- Nos equipamentos de extração do caldo (moendas, caixas, peneiras, tubulações) há sempre focos de crescimento das bactérias láticas, pois amostras retiradas após esse trajeto apresentaram contagens superiores às do caldo misto, ocorrendo também ligeiro abaixamento do $\mathrm{pH}$.

- A calagem ou sulfitação e calagem seguida do tratamento térmico permitem uma redução substancial na contagem microbiana.

- Nas dornas em fermentação, o controle de bactérias láticas é essencial.

- Para que a contaminação lática seja mantida em um nível adequado há necessidade de intensificar o controle do pé-de-cuba.

- O controle microbiológico é de importância fundamental se o objetivo é produzir álcool com altos rendimentos (Amorim e Oliveira, 1982). Segundo esses autores, a diminuição da produção de álcool pode ser causada por diversos motivos, tais como: consumo de açúcar pelo microrganismo contaminante; consumo do álcool produzido (como no caso das bactérias acéticas), morte de células de leveduras por toxinas lançadas ao meio pelos microrganismos contaminantes ou pelo excesso de ácido 
ou outro produto utilizado para combater a contaminação, e perdas de células de leveduras no fundo das dornas ou nas centrífugas causadas pela floculação do fermento, devido à "goma" produzida pelas bactérias. Quando uma contaminação se instala, o tempo de fermentação fica mais longo, devido à redução da concentração de fermento nas dornas.

Alguns compostos podem ser originados do metabolismo de alguns tipos de bactérias, como é o caso da dextrana e da levana, que são o resultado da ação de bactérias do gênero Leuconostoc e Bacillus sobre a sacarose, desdobrando-a e dando formação a polímeros de alto peso molecular, que são constituídos por resíduos de glicose ou de frutose. É fácil notar a presença destas bactérias pois esses polímeros entopem trocadores de calor, canalizações, bombas, causam problemas de cor e são vulgarmente chamados de "cangica" ou "cangiquinha". Além disso, esses polímeros aumentam a viscosidade do vinho, entupindo as centrifugas ou diminuindo sua capacidade (Amorim e Oliveira, 1982; Lima et al., 1974).

Essia Ngang et al. (1990), estudando a inibição da fermentação alcoólica de melaço de beterraba por Lactobacillus, concluíram que o ácido lático e produtos associados, especialmente ácido acético, são liberados no meio e induzem uma inibição que é reforçada pela presença de lactobacilos viáveis.

Narendranath, et al. (1997), estudaram o efeito de diferentes espécies de lactobacilos, em diferentes concentrações, no crescimento da levedura e no rendimento em etanol em mosto de malte de trigo e concluíram que o decréscimo do rendimento em etanol em amostras contaminadas (de aproximadamente $2 \%$ com uma contaminação de 
$10^{6} \mathrm{UFC} / \mathrm{ml}$ e 3,8 a $7,6 \%$ com uma contaminação de $10^{9} \mathrm{UFC} / \mathrm{ml}$ - dependendo da espécie) foi devido ao desvio de carboidratos para o crescimento bacteriano e produção de ácido lático $[0,5 \%(\mathrm{p} / \mathrm{v})$ no caso de bactérias heterofermentativas e 1 a $1,5 \%(\mathrm{p} / \mathrm{v})$ no caso de bactérias homofermentativas]. Eles acharam também que a competição entre leveduras e bactérias por fatores de crescimento foi uma importante razão que diminuiu o crescimento da levedura e o conseqüente rendimento final em etanol.

Alterthum et al. (1984) observaram que, quando se utilizam as células provenientes da fermentação anterior, nota-se uma queda de $30,4 \%$ em relação ao rendimento de uma prova em branco. Verifica-se ainda o gradativo aumento do número de leveduras mortas, nos ensaios altamente contaminados e a crescente sobra do substrato fermentescivel. Esses autores notaram também uma correlação positiva existente entre a acidez do vinho e o número de células bacterianas presentes no mosto e uma correlação negativa existente entre este último parâmetro e o rendimento alcoólico do processo. Os mesmos concluíram que a elevada porcentagem de leveduras mortas, bem como o aumento da acidez do mosto, e a provável liberação de substâncias tóxicas ao meio da cultura pelas células bacterianas, promovem a morte das células de levedura ou dificultam o seu desenvolvimento. Da mesma maneira, a grande sobra de açúcar residual presente no mosto já fermentado, confirma o fato de que as células de leveduras existentes estão enfraquecidas e incapacitadas de utilizar adequadamente o substrato disponível; por outro lado, o baixo rendimento em etanol encontrado não justifica a elevada concentração de açúcar consumido, sugerindo que a mesma tenha sido destinada 
à formação de outros produtos ou que o etanol formado tenha sido consumido pelos microrganismos contaminantes. Esses autores concluíram que:

- Quedas no rendimento alcoólico, variáveis de 14 a $90 \%$ do teórico, foram verificadas quando a concentração bacteriana cresceu de $10^{8}$ a $10^{9}$ células $/ \mathrm{ml}$.

- Os parâmetros acidez do vinho, contagem do número de bactérias presentes no mosto e porcentagem de leveduras viáveis, são importantes na avaliação do processo infeccioso.

- Os principais microrganismos contaminantes encontrados nas microdestilarias foram bactérias do tipo coco e bacilo, gram positivos.

- Equipamentos do tipo difusor podem auxiliar o controle da população bacteriana existente nas dornas.

Estudando o efeito de alguns produtos secundários no sistema de fermentação, Maiorella et al. (1983) concluíram que o etanol causa uma retroinibição em sua produção; que o ácido fórmico causa uma interferência química com manutenção das funções celulares; que o ácido acético, o ácido lático, o 1-propanol, o 2-metil-1-butanol, o 2,3-butanodiol e o acetaldeído causam interferências químicas e que o glicerol e a glicose causam efeitos na pressão osmótica.

Esses mesmos autores acharam também que a concentração de ácido acético (um dos produtos finais de bactérias láticas heterofermentativas e leveduras selvagens e o principal produto final de bactérias aeróbicas como Acetobacter sp.) e ácido lático, inibiram o crescimento de $S$. cerevisiae quando presente em concentrações de 0,5 a 9 e 
10 a 40 g/litro, respectivamente, e uma redução de $80 \%$ na massa de células de levedura ocorreu em concentrações de 7,5 e 38 g/litro, respectivamente.

A redução no $\mathrm{pH}$ do meio devido à produção de lactato pode também inibir o processo de sacarificação (Ingledew, 1993; Makanjuola, 1992). Apesar de uma significante soma de pesquisas na área, o efeito de bactérias láticas em fermentações catalizadas por leveduras permanece confuso (Huang et al. 1996).

Qualquer correlação entre o tamanho da contaminação bacteriana e perdas em rendimento em etanol precisa ainda ser melhor compreendida, embora seja óbvio que cada molécula de açúcar direcionada para a produção de ácido lático pela bactéria resulta em perda de duas moléculas de etanol que poderiam ser produzidas pelas células de leveduras (Ingledew, 1995). Quando contaminantes bacterianos são comparados, o problema da correlação da perda de rendimento em etanol com a presença de ácido lático e/ou acético é complicada em parte pelo fato de bactérias láticas homofermentativas metabolizarem glicose a ácido lático quase que estequiometricamente, enquanto bactérias láticas heterofermentativas produzem ácido lático, $\mathrm{CO}_{2}$, e etanol e menores quantidades de glicerol e ácido acético a partir da glicose.

Essia Ngang et al. (1989), estudaram os efeitos da adição de ácido lático em parâmetros da fermentação alcoólica de leveduras em melaço de beterraba, já que entre os metabólitos microbianos, o ácido lático é o componente principal. Os autores observaram que o ácido lático afeta a taxa de crescimento da levedura e a taxa de produção de álcool de diferentes maneiras dependendo da pressão osmótica do mosto; o 
crescimento da levedura é o parâmetro mais afetado. O uso de um grande inóculo de levedura conduz a um decréscimo dos fenômenos de inibição observados.

Noda et al. (1980) ao pesquisarem o antagonismo entre bactérias láticas osmofilicas e leveduras na fermentação de molho de soja (shoyu), reconheceram que leveduras osmofilicas do shoyu, como Saccharomyces rouxii e Torulopsis versatilis foram inibidas pelos metabólitos produzidos por bactérias láticas osmofilicas (pertencente à espécie Pediococcus halophilus). $\mathrm{O}$ inibidor principal foi considerado o ácido acético, embora o ácido lático tenha causado uma ligeira inibição.

Segundo Tani et al. (1963), a levedura Saccharomyces cerevisiae pode ser inibida pelo ácido lático produzido por Lactobacillus sake.

Há dois fatores relevantes quando se avalia o custo/benefício da utilização de antibióticos na fermentação alcoólica, segundo Stroppa et al. (1998): o consumo de açúcar pelos contaminantes e o produto do metabolismo dessas bactérias.

Yokoya e Oliva-Neto (1991), estudando a relação entre leveduras e algumas linhagens de Lactobacillus fermentum isoladas de destilarias de álcool, constataram que algumas linhagens eram capazes de provocar floculação enquanto outras não. Segundo Santos e Yokoya (1992), algumas linhagens de Lactobacillus fermentum são responsáveis pela floculação de leveduras.

$\mathrm{O}$ etanol, em concentrações inferiores a $2 \%$, tem sido apontado por King e Beelman (1986) como estimulante do crescimento bacteriano no cultivo misto com leveduras.

Estudos da contaminação bacteriana durante a fermentação alcoólica tem caracterizado os aminoácidos oriundos da levedura morta como sendo importante para a 
nutrição e o desenvolvimento de lactobacilos no processo. Os aminoácidos são fatores fundamentais presentes, sem os quais não ocorre o desenvolvimento de Lactobacillus na fermentação alcoólica (Oliva-Neto e Yokoya, 1996). Dentre esses aminoácidos, leucina, isoleucina e valina quando adicionados ao caldo de cana-de-açúcar estimulam o crescimento de L. fermentum, mas, a tirosina, o ácido aspártico ou a lisina não se mostram essenciais (Oliva-Neto e Yokoya, 1997).

De fato, o extrato de levedura pode estimular o crescimento de bactérias láticas. Smith et al. (1975) utlilizando-se de extrato de levedura fracionado em Sephadex G-25 em 7 frações, constataram que, a fração mais estimulatória para o crescimento da bactéria lática Streptococcus lactis C10 continha acima de 70\% do nitrogênio presente no extrato de levedura e consistia de uma ampla variedade de aminoácidos livres e uma pequena soma de materiais peptídicos. Um exame mais apurado revelou que os aminoácidos presentes foram os grandes responsáveis pela estimulação de crescimento do $S$. lactis $\mathrm{C} 10$. Bases púricas e pirimidínicas também contribuíram para esta estimulação.

Diversos autores (Silva e Canhos, 1990; Gallo, 1990) caracterizaram a microbiota contaminante e encontraram como principais contaminantes linhagens de Lactobacillus fermentum. Amorim e Oliveira (1982) também se referem às bactérias do gênero Lactobacilos, como sendo uma das mais atuantes e geralmente associadas com fracassos da fermentação alcoólica devido à formação de ácido lático e outros ácidos orgânicos. Igualmente, Borzani (1986) e Aquarone (1960) tem descrito a inibição da fermentação alcoólica por bactérias láticas. 
Bactérias láticas isoladas de destilarias são bem adaptadas às condições existentes em ambientes fermentativos (Bryan-Jones, 1975). Por outro lado, bactérias aeróbias e anaeróbias facultativas, com tolerância a pH baixos, não são consideradas sérias comprometedoras da qualidade do produto e da eficiência do processo de produção.

Quando leveduras e bactérias láticas crescem juntas em um meio definido no qual o crescimento da levedura é restringido através de uma concentração subótima de vitaminas, algumas substâncias essenciais (ácido nicotínico, adenina, guanina, ácido aspártico, triptofano, glicina, alanina ou lisina) para o crescimento de Lactobacillus spp são fornecidas ao meio pelas células de leveduras (Challinor e Rose, 1954).

Existem controvérsias na literatura descrevendo o efeito de bactérias láticas sobre o rendimento em etanol. Chin e Ingledow (1994) relataram que Lactobacillus fermentum inoculados em aproximadamente $10^{8}$ UFC/ml não afetaram seriamente a produtividade em etanol na fermentação de malte de trigo ( $14^{\circ}$ Plato), onde somente um moderado crescimento da bactéria foi relatado. Outros pesquisadores, de qualquer modo, tem relatado que quando o número de bactérias excede $10^{8} \mathrm{UFC} / \mathrm{ml}$ em 30 horas de fermentação, a perda em álcool é de aproximadamente 5\% (Barbour e Priest, 1988; Dolan, 1979). De acordo com Makanjuola et al. (1992), queda no rendimento em etanol, baixo crescimento da levedura, menor utilização de carboidratos e aumento da acidez foram todos causados pela produção de ácido lático. Eles encontraram que uma contagem de bactéria de $4.5 \times 10^{8} \mathrm{UFC} / \mathrm{ml}$ em $30 \mathrm{~h}$ resulta em uma redução de $17 \%$ no rendimento em etanol. 
Inúmeros artigos indicam que uma intensa fermentação lática resulta na depressão da fermentação alcoólica durante a fermentação de shoyu, salsichas, presuntos e derivados do leite (Dahiya e Speck, 1968; Gilliland e Speck, 1972; Price e Lee, 1970).

\subsection{Lactobacillus fermentum}

São bactérias tipo bastonetes, gram-positivos, não-esporulantes e regulares. Possuem uma espessura entre $0,5-0,9 \mu \mathrm{m}$ e um comprimento amplamente variável. A temperatura ótima de crescimento é $45^{\circ} \mathrm{C}$, não crescendo abaixo de $15^{\circ} \mathrm{C}$. L. fermentum tem sido comumente isolado de produtos de leite, massa de farinha azeda, materiais de plantas em fermentação, vinho, silagem, água de esgoto e bocas e fezes do homem e de ratos. Os lactobacilos são organismos extremamentes fastidiosos, adaptados a substratos organicamente complexos, não requerendo somente carboidratos (como fonte de energia), mas também nucleotídeos, aminoácidos e vitaminas. Entre as últimas destacam-se o pantotenato de cálcio, a niacina e a tiamina. O modelo de requerimento de aminoácidos difere entre as espécies e até mesmo entre as linhagens. Os vários nutrientes essenciais são normalmente encontrados quando o meio contém carboidratos fermentescíveis, peptona, carne e extrato de levedura. Os lactobacilos crescem melhor em meios de $\mathrm{pH}$ ligeiramente ácidos entre $6,4 \mathrm{a} 4,5$. O crescimento cessa quando o $\mathrm{pH}$ atinge 4,0 - 3,6, dependendo da espécie e da linhagem. Embora a maioria das linhagens sejam aerotolerantes, um ótimo crescimento é encontrado sobre condições 
microaerófilas e anaeróbias. Um aumento na concentração de $\mathrm{CO}_{2}$ (ao redor de $5 \%$ ) pode estimular o seu crescimento. (Kandler e Weiss, 1986).

Muitas espécies de lactobacilos parecem ter se adaptado às condições ambientais específicas e, geralmente, não foram encontradas fora de seu habitat mais especializado (London, 1976). O metabolismo dessas bactérias explica essa seletividade ambiental, afinal não possuem o ciclo de Krebs e a cadeia respiratória clássica, o que as limita a ambientes de baixa concentração de $\mathrm{O}_{2}$ (microaerofilia), possuindo um limiar de vida de anaerobiose-para-aerobiose (Kandler e Weiss, 1986).

Leveduras e bactérias láticas são freqüentemente encontradas juntas em ecossistemas naturais e podem competir pelos mesmos nutrientes (Alexander, 1971).

\subsection{Aspectos do metabolismo de carboidratos de bactérias láticas}

Em relação ao metabolismo de carboidratos, uma grande diferenciação foi feita entre os lactobacilos baseada nas características clássicas de subgêneros de ORLAJENSEN (1919) ${ }^{1}$, citado por Kandler e Weiss (1986), e três grupos foram definidos. O grupo I - Lactobacilos obrigatoriamente homofermentativos que via fermentação convertem 1 mol de hexose em 2 mols de ácido lático via Embden-Meyerhof, e não fer-

\footnotetext{
${ }^{1}$ ORLA-JENSEN, S. The lactic acid bacteria. Copenhagen: Hostand Son, 1919.
} 
mentam pentoses e gluconato. O grupo II - Lactobacilos facultativamente heterofermentativos que fermentam hexoses como os do grupo I, exceção a poucas espécies que produzem outros ácidos, em condições limitadas de glicose, pentoses são fermentadas produzindo acido acético e lático via fosfocetolase indutível. O grupo III lactobacilos obrigatoriamente heterofermentativos que utilizam a via do 6fosfoglucanato, que fermentam hexoses resultando em 1 mol de $\mathrm{CO}_{2}, 1 \mathrm{~mol}$ de etanol (ou ácido acético) e $1 \mathrm{~mol}$ de ácido lático, pentoses são fermentadas a ácido lático e acético.

A maioria das linhagens de $L$. fermentum são capazes de fermentar os seguintes carboidratos: frutose, galactose, glucose, gluconato, lactose, maltose, manose, melibiose, rafinose, ribose e sacarose. Algumas linhagens fermentam ainda: arabinose, celobiose, trealose e xilose.

A maioria dos sacarídeos e oligossacarídeos são capturados com a ajuda de permeases específicas e são fosforilados dentro da célula. Os oligossacarídeos são partidos por glicosidases respectivas antes da fosforilação resultando em monossacarídeos. De qualquer modo, ao menos lactose e galactose são absorvidos por alguns lactobacilos, via sistema fosfotransferase fosfoenolpiruvato-dependente (Chassy e Thompson, 1983). 


\subsection{Invertase}

A sacarose, dissacarídeo não-redutor, é formada por D-glicose e D-frutose unidas através de seus carbonos anoméricos, mediante ligação glicosídica, e como tal não é absorvida pela levedura, sendo hidrolisada extracelularmente pela invertase da levedura:

$$
\text { sacarose }+\mathrm{H}_{2} \mathrm{O} \rightarrow \text { D-frutose }+\mathrm{D} \text {-glicose }
$$

Os monossacarídeos assim formados são fosforilados e convertidos em intermediários da glicólise.

A levedura Saccharomyces cerevisiae possui várias enzimas ligadas extermamente à sua membrana celular, as quais estão prontamente acessíveis aos substratos. Este é o caso da invertase externa. A levedura possui também a invertase intracelular. $\mathrm{O}$ peso molecular e a atividade específica da enzima interna são semelhantes ao da enzima externa, mas a composição de aminoácidos é diferente (Gascón et al., 1968).

A atividade invertásica de células de leveduras intactas é oscilante. Vitolo et al. $(1985 ; 1987)$ estudaram a atividade de invertase de células de $S$. cerevisiae, em melaço de cana em testes com cultura contínua constante e não-constante e concluíram que durante o cultivo contínuo de leveduras a parede celular e o espaço periplasmático são submetidos a mudanças morfológicas contínuas as quais afetam a interação entre a invertase e moléculas de sacarose, conduzindo à oscilação da atividade invertásica.

A atividade de invertase é diferente entre diferentes linhagens e aumenta durante a fermentação, mas independe da viabilidade celular. A atividade de invertase das células, assim como a ótima temperatura para crescimento e a velocidade de formação 
do etanol são dependentes da composição do meio e do tipo de linhagem utilizada (Laluce et al., 1991).

Vitolo e Yassuda (1991), estudando o efeito da concentração de sacarose na atividade invertásica de células intactas de leveduras (S. cerevisiae), verificaram que a atividade invertásica para ambas as formas (solúvel e ligada à parede celular) variou ao redor de $10 \%$ para concentrações de sacarose entre 80 e $200 \mathrm{~g} / \mathrm{l}$, já que a atividade de transferase aumentou marcadamente com o aumento da concentração de sacarose.

Vitolo et al. (1995) com o propósito de determinar a melhor condição de cultura para evitar uma repressão pela glicose e a oscilação da atividade invertásica, assim como para obter células de Saccharomyces cerevisiae com alta atividade final de invertae crescendo em meio de melaço de cana, encontrou que, quando a concentração de glicose (S) é maior que $0,5 \mathrm{~g} . \mathrm{L}^{-1}$, a redução na atividade específica de invertase de células intactas (v) e o comportamento oscilatório do valor de $\mathrm{v}$ durante a fermentação é observado. Ambas, a redução da invertase e o comportamento oscilatório de v podem ser relacionados com o efeito inibitório da glicose na biossíntese de invertase. A melhor condição de cultura para as células de $S$. cerevisiae alcançarem uma adequada produção de invertase foram: temperatura $=30^{\circ} \mathrm{C} ; \mathrm{pH}=5.0 ; \mathrm{DO}=3.3 \mathrm{mg} \mathrm{O}_{2} \mathrm{~L}^{-1} ;(\mathrm{S})=0.5 \mathrm{~g} \mathrm{~L}^{-1}$ e sacarose adicionada ao fermentador de acordo com a equação: (V-Vo) $=\mathrm{t}^{2} / 16$ ou (V$\left.V_{0}\right)=\left(V_{f}-V_{0}\right) \cdot\left(e^{0.6 t}-1\right) / 10$

O efeito do $\mathrm{pH}$ (de 4.0 a 5.0 ), temperatura $\left(\right.$ de $30^{\circ} \mathrm{C}$ a $40^{\circ} \mathrm{C}$ ) e concentração do oxigênio dissolvido (de 0.2 a $6.0 \mathrm{mg} \mathrm{O}_{2} / \mathrm{L}$ ) na formação de glicose 6-fosfato desidrogenase (G6PDH) (EC1.1.1.49) e invertase (EC 3.2.1.26) por S. cerevisiae foram 
estudados por Abrahão-Neto et al. (1997). As melhores condições de cultura para a formação de G6PDH e invertase foram: $2.55 \mathrm{~L}$ de meio de cultura $(3.0 \mathrm{~g} / \mathrm{L}$ de extrato de levedura; $5.0 \mathrm{~g} / \mathrm{L}$ de peptona; $2.0 \mathrm{~g} / \mathrm{L}$ de glicose; $15.0 \mathrm{~g} / \mathrm{L}$ de sacarose; $2.4 \mathrm{~g} / \mathrm{L}$ de $\mathrm{Na}_{2} \mathrm{HPO}_{4} .12 \mathrm{H}_{2} \mathrm{O} ; 5.1 \mathrm{~g} / \mathrm{L}$ de $\left(\mathrm{NH}_{4}\right)_{2} \mathrm{SO}_{4}$ e $0.075 \mathrm{~g} / \mathrm{L}$ de $\left.\mathrm{MgSO}_{4} .7 \mathrm{H}_{2} \mathrm{O}\right) ; 0.45 \mathrm{~L}$ de inóculo $(0.70 \mathrm{~g}$ de célula seca/ $\mathrm{L}) ; \mathrm{pH}=4.5 ; \mathrm{T}=35^{\circ} \mathrm{C}$; e $\mathrm{DO}=4.0 \mathrm{mg} / \mathrm{L}$. Quanto à atividade de invertase ( $\mathrm{AI}$ ) eles concluíram que a $\mathrm{AI}$ de todas as células decresceram no mínimo $50 \%$ a valores extremos de DO $(2.0$ e $6.0 \mathrm{mg} \mathrm{O} / \mathrm{L})$ e $\mathrm{pH}(4.0$ e 5.0$)$. Além disso, a atividade de invertase oscilou durante a fermentação devido ao mecanismo de repressão/desrepressão da glicose.

Vitolo et al. (1991), a partir da determinação da atividade de invertase de células de leveduras colhidas de fermentação alcoólica de melaço em batelada, assumiram que a atividade de invertase presente nessas células de leveduras residuais ainda eram significantes, mesmo sendo o processo fermentativo originalmente designado somente para a produção de etanol, e que portanto, a extração de invertase ou outras enzimas como produtos secundários pode ser uma atividade lucrativa para destilarias, já que as enzimas são atualmente caracterizadas como produtos de valor agregado.

Bokassa et al. (1993), estudando uma linhagem de $S$. cerevisiae (01K32) com grande potencial para a síntese de invertase, observaram que um meio de melaço com $3 \%$ de ART é um substrato ideal para uma rápida produção dessa enzima.

Takeshige e Ouchi (1995) estudaram os efeitos da invertase de levedura na produção de etanol em meio de melaço. Seus achados indicam que uma das características requeridas para uma levedura ser utilizada na produção industrial de 
álcool é uma forte atividade de invertase para a hidrólise da sacarose sobre condições inibitórias existentes em meio de melaço. Eles descreveram um efeito negativo da osmolaridade na fermentação etanólica, e o importante papel da invertase na regulação osmótica em melaços. Se a atividade de invertase for muito fraca, o suprimento do hidrolizado para a fermentação é insuficiente, mas se for muito forte, a rápida hidrólise de sacarose aumenta a osmolaridade, e como resultado, a produção de etanol é deprimida. Idealmente o suprimento de monossacarídeos pela levedura deveria ser bem balanceado com o seu consumo, assim, a osmolaridade no meio permaneceria mínima durante a fermentação.

Park e Sato (1982) conduziram estudos comparativos de fermentação de melaços de cana em etanol por Saccharomyces cerevisiae na presença e ausência de invertase fúngica. Quando melaços de cana foram fermentados pela levedura a $30^{\circ} \mathrm{C}$ e $\mathrm{pH} 5.0$, a presença da enzima não causou nenhum efeito na produção de etanol. A um pH 3.5, a produção de etanol foi aumentada pela adição de invertase. A $40^{\circ} \mathrm{C}$, a adição de invertase aumentou a produção de etanol em 5,5\% a pH 5.0 e em $20,9 \%$ a pH 3.5 .

A atividade de bactérias láticas é grandemente facilitada em meios fermentativos com a presença de invertase. Aksu e Kutsal (1986) aumentaram a taxa e o rendimento de produção de ácido lático a partir de melaço, adicionando invertase ao meio. A conversão da sacarose em monossacarídeos aumentou o rendimento da fermentação pela bactéria lática Lactobacillus delbrüeckii em 13\%. Bucker et al. (1979) constataram que o tratamento do leite de amendoim com invertase possibilitou a fermentação com 13 culturas de bactérias láticas, que antes do tratamento não foram capazes de fermentar a sacarose do leite e, assim não produziram ácido lático. 
Gobbetti et al (1994), ao estudar interações entre Lactobacillus e Saccharomyces em co-cultura usando meio sintético, concluíram que a liberação adequada de monossacarídeos através da hidrólise da sacarose pela levedura, modificou a interação metabólica entre leveduras e bactérias láticas, facilitando a fermentação lática por $L$. brevis subspécie lindneri CB1 e L. plantarum DC 400, tendo como substrato farinha azeda.

Em um estudo sobre a interação entre leveduras e bactérias láticas em melaço de beterraba, Essia Ngang et al. (1992) concluíram que os monossacarídeos liberados durante a hidrólise da sacarose pela levedura foram os responsáveis pelo estímulo ao crescimento bacteriano. 


\section{MATERIAIS E MÉTODOS}

EXPERIMENTO 1: (1 ${ }^{\mathrm{a}}$ PARTE)

3.1 Análise do teor de invertase nos vinhos de diferentes leveduras:

3.1.1 Leveduras: Foram utilizadas cinco diferentes linhagens de Saccharomyces cerevisiae: PE-2, BG-1, CAT-1, IZ-1904 e FLE (levedura de panificação). Todas as linhagens foram obtidas à partir da coleção de leveduras do Departamento de Ciências Biológicas da ESALQ/USP. Essas leveduras foram mantidas em meio YEPD-ágar com óleo mineral a temperatura ambiente, conforme mostra a figura abaixo. (Figura 1) 
Cariotipagem das diferentes linhagens de leveduras

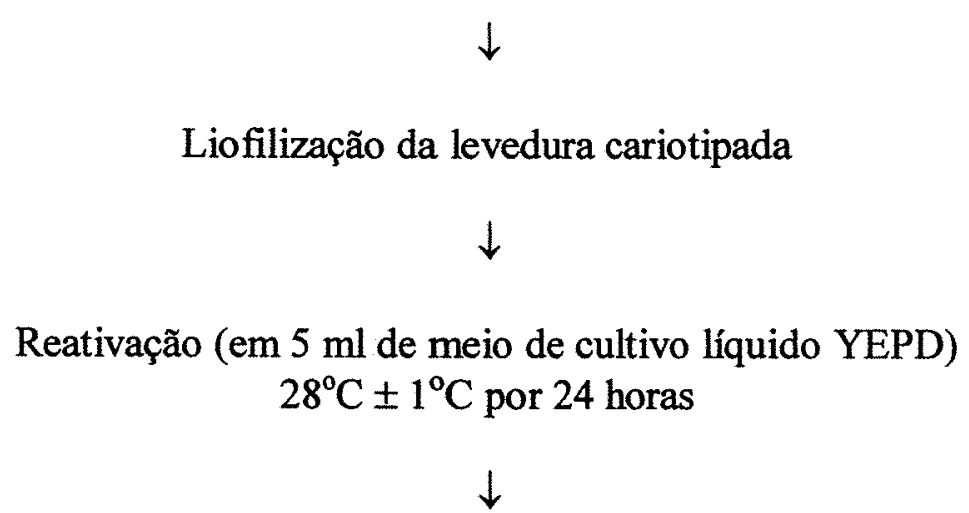

Cultura de levedura reativada

$\downarrow$

Propagação sob superficie ("estria") em tubos de ensaio com YEPD-ágar inclinado $28^{\circ} \mathrm{C} \pm 1^{\circ} \mathrm{C}$ por 48 horas

$\downarrow$

Introdução no tubo de óleo mineral líquido esterilizado Armazenamento à temperatura ambiente.

Figura 1 - Esquema de estocagem das leveduras

3.1.2 Multiplicação das leveduras: foi realizada em tubos com $20 \mathrm{~mL}$ de meio YEPD a partir de culturas puras estocadas e propagada anaerobicamente, a temperatura ambiente $\left(28 \pm 1^{\circ} \mathrm{C}\right)$ por 24 horas. A suspensão de células foi então transferida para frascos do tipo erlenmeyers com $200 \mathrm{~mL}$ de meio de caldo de cana-de-açúcar (6\% ART) ou mosto misto ( $70 \%$ de caldo de cana com $6 \%$ de ART e $30 \%$ de melaço com $6 \%$ de ART) 
prosseguindo o crescimento a temperatura ambiente $\left(23 \pm 3^{\circ} \mathrm{C}\right)$ por $66,70,90$ ou 94 horas. (Figura 2)

3.1.3 Análise da invertase nos vinhos: Tanto no meio de caldo de cana como no meio de mosto misto (caldo + melaço) a atividade de invertase foi dosada 66, 70, 90 e 94 horas após a inoculação com as diferentes leveduras. Esses horários foram previamente estipulados por coincidirem com o término do crescimento das leveduras. Portanto nesses horários os meios já foram transformados em vinho não restando açúcares que poderiam interferir na análise da invertase. (Figura 2)

3.1.4 Procedimento: Retirou-se uma alíquota de $10 \mathrm{~mL}$ do vinho previamente homogeneizado (com 66, 70, 90 e 94 horas após inoculação). Esse vinho foi centrifugado (800 x G por 15 minutos) e convenientemente diluído (diluị̧ão previamente estipulada) para dosagem da atividade enzimática. Da biomassa centrifugada obteve-se o teor de fermento. (Figura 2) 
sobrenadante

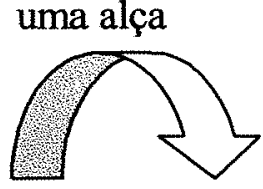

9

Tubo Inclinado com óleo mineral $28^{\circ} \mathrm{C} / 24$ hs

(leveduras PE, BG, FLE, IZ ou CAT)

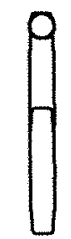

$20 \mathrm{~mL}$ YEPD

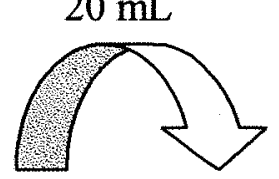

frasco todo

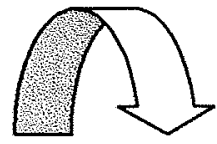

Homoge- 15 minutos)

\section{Neização}

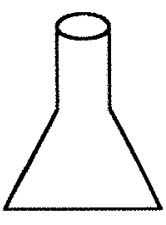

$200 \mathrm{~mL}$ de meio (caldo de cana ou mosto misto)

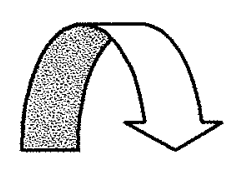

Diluição

(1:10)

ENSAIO

ENZI-

MÁTICO

Figura 2 - Esquema da análise do teor de invertase no vinho de caldo de cana e de mosto misto de diferentes leveduras.

3.1.5 Ensaio enzimático: Foi adaptado da metodologia proposta por Villela et al., 1973. Em 6 tubos de ensaio, enumerados de 0 a 5 , foram pipetados volumes crescentes de sacarose 12,5 mM. Esses tubos foram ajustados com água para um volume de 2,0 mL. Após isso foi acrescentado em cada tubo $0,5 \mathrm{~mL}$ da invertase diluída (diluição previamente estipulada) em vinho ou água. Em um tubo à parte foi colocado apenas a 
solução de sacarose e água, e em um último tubo foi colocado $2,5 \mathrm{~mL}$ de uma solução padrão contendo $100 \mu \mathrm{g}$ de glicose.

Os tubos (exceto o que continha a solução padrão) foram incubados a $37^{\circ}$, por 15 minutos, para que a invertase catalisasse a hidrólise da sacarose, resultando na formação de glicose e frutose, os quais foram determinados pela reação de Somogyi-Nelson (Bacila, 1960; Nelson, 1944), sendo que os teores de açúcares redutores formados foram convertidos em atividade de invertase $\left(\mu \mathrm{g} \mathrm{AR} \cdot \mathrm{h}^{-1}\right)$. Para o cálculo da atividade específica $\left(\mu \mathrm{g} \mathrm{AR} \cdot \mathrm{h}^{-1} \cdot \mathrm{mg} \mathrm{lev}{ }^{-1}\right)$ considerou-se o teor de fermento no meio.

A solução de sacarose, a diluição da enzima, a água utilizada para ajustar os tubos e a solução padrão foram preparadas com pH ajustado para 4,6 com ácido acético glacial.

3.1.6 Reação para dosagem de açúcares redutores: Vitolo e Borzani (1983) sugerem o método de Somogyi e Nelson como o mais conveniente para bloquear rápida e efetivamente a atividade de invertase. Portanto, para a determinação colorimétrica de açúcares redutores utilizou-se o método de Somogyi e Nelson (Bacila, 1960; Nelson, 1944). Tão logo deu-se o término do período de incubação (15 minutos) foi acrescentado $1 \mathrm{~mL}$ do reativo de Somogyi (a reação enzimática é paralizada pela desnaturação da invertase, quer pela ação do $\mathrm{Cu}^{++}$quer pela alcalinidade do reagente). Os tubos foram fervidos em banho-maria por 10 minutos, resfriados e juntou-se $1 \mathrm{~mL}$ do reativo de Nelson. Após agitação o volume foi completado a $10 \mathrm{~mL}$ (adicionando-se 5,5 mL de água destilada), foi agitado novamente e foi feita a leitura em um fotocolorímetro KlettSummerson (filtro $\mathrm{n}^{0} 54$ ). 
EXPERIMENTO 1: (2 ${ }^{\mathrm{a}}$ PARTE)

3.2 Análise do teor de invertase do espaço periplasmático de diferentes leveduras:

3.2.1 Leveduras: Foram utilizadas as mesmas linhagens de leveduras: PE-2, BG-1, CAT-1, FLE e IZ.

3.2.2 Multiplicação das leveduras: Foi realizada em frascos com $50 \mathrm{~mL}$ de meio YEPD a partir de culturas-estoques ( $28 \pm 1^{\circ} \mathrm{C} / 24$ horas), sendo a suspensão de células transferida para frascos do tipo erlenmeyers com $1 \mathrm{~L}$ de meio de crescimento de melaço com $6 \%$ de ART, suplementado com $\mathrm{KH}_{2} \mathrm{PO}_{4}(0.87 \mathrm{~g} / \mathrm{L}),\left(\mathrm{NH}_{4}\right)_{2} \mathrm{SO}_{4}(0.66 \mathrm{~g} / \mathrm{L})$, uréia $(0.66 \mathrm{~g} / \mathrm{L}), \mathrm{MgSO}_{4} \cdot \mathrm{H}_{2} \mathrm{O}(0.49 \mathrm{~g} / \mathrm{L}), \mathrm{ZnSO}_{4} \cdot 7 \mathrm{H}_{2} \mathrm{O}(0.03 \mathrm{~g} / \mathrm{L}), \mathrm{MnSO}_{4} \cdot \mathrm{H}_{2} \mathrm{O}(0.02 \mathrm{~g} / \mathrm{L})$ e ácido linolêico $(0.03 \mathrm{~g} / \mathrm{L})$, prosseguindo o crescimento a temperatura ambiente $(23 \pm$ $3^{\circ} \mathrm{C}$ ) por 70 horas. (Figura 3 )

3.2.3 Análise da invertase nos vinhos: A atividade de invertase foi dosada no vinho 70 horas após a inoculação utilizando-se a mesma metodologia descrita no ítem 3.1.4. Após isso $\mathrm{o}$ vinho mais as leveduras foram postos para decantar em uma câmara fria $\left(8 \pm 1^{\circ} \mathrm{C}\right)$ por mais 60 horas. Para a obtenção de 5 gramas de matéria úmida, a mesma foi separada do vinho mediante centrifugação ( $800 \mathrm{X} \mathrm{G}$, por 20 minutos). (Figura 3) 
Obtenção da massa fresca de levedura para extração (ver abaixo)

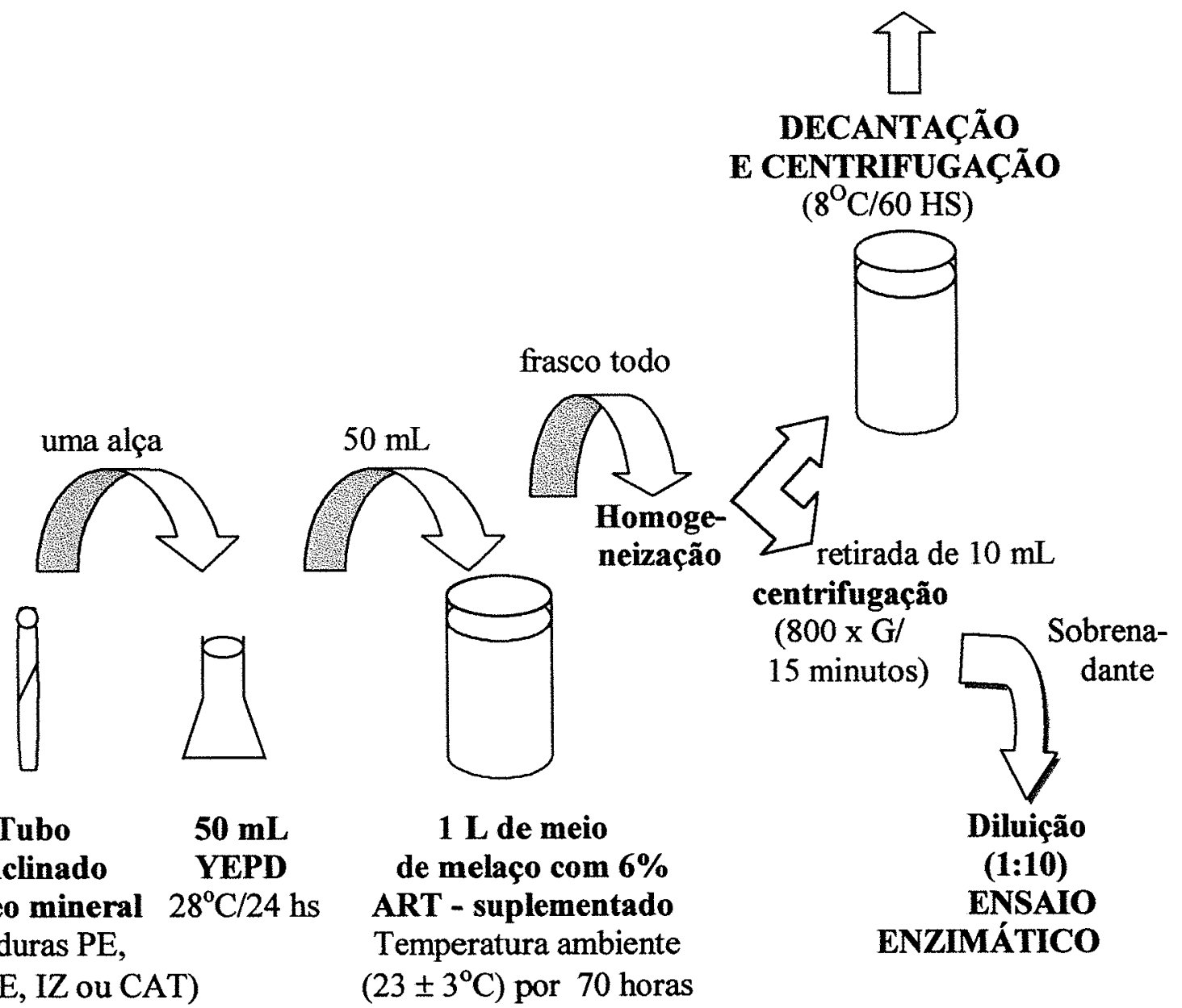

Figura 3 - Esquema da análise do teor de invertase no vinho de melaço e do autolisado de diferentes leveduras.

3.2.4 Procedimento - Preparação do extrato bruto (Suco de Lebedev): 5 gramas de massa úmida centrifugada de levedura foram suspensas em $15 \mathrm{~mL}$ de bicarbonato de sódio $\left(\mathrm{NaHCO}_{3}-500 \mathrm{mM}\right)$ e mantidas a $45^{\circ} \mathrm{C}$ durante 5 horas para necessária autólise. A seguir, $2 \mathrm{~mL}$ da suspensão foram adicionados a $3 \mathrm{~mL}$ de água e centrifugados por 10 minutos a $800 \mathrm{G}$, o sedimento foi desprezado, sendo o sobrenadante diluído (1:50) com 
água destilada e submetido à dosagem enzimática de invertase. Este procedimento foi adaptado da metodologia proposta por Villela et al., 1973. (Figura 4)

\section{EXTRAÇÃO:}

$5 \mathrm{~g}$ de matéria fresca de levedura

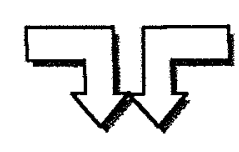

$15 \mathrm{~mL}$ de $\mathrm{NaHCO}_{3}$

$500 \mathrm{mM}$

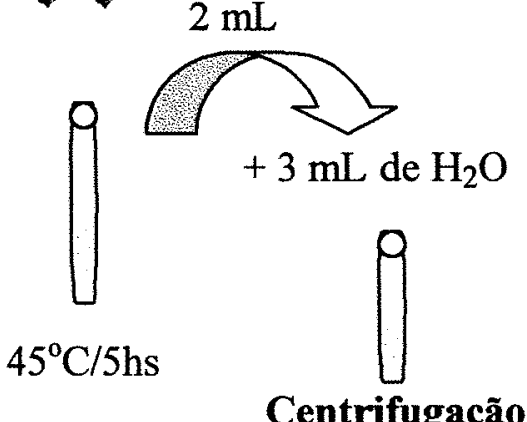

sobrenadante

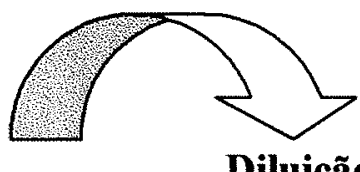

Diluiçãa

(1:50)

ENSAIO

ENZIMÁTICO

Figura 4 - Esquema da extração da invertase do espaço periplasmático de diferentes leveduras.

3.2.5 Ensaio enzimático: Conforme ítem 2.1.5.

3.2.6 Reação para dosagem de açúcares redutores: Conforme ítem 2.1.6. 


\section{EXPERIMENTO 2:}

\subsection{Crescimento de lactobacilos em meios obtidos dos vinhos de diferentes}

\section{leveduras}

\subsubsection{Curva de calibração de L. fermentum}

- Bactéria: Foi utilizada a bactéria Lactobacillus fermentum (CCT 1407) não floculante, isolada de destilaria e oriunda da Coleção da Fundação Tropical de Pesquisa e Tecnologia André Tosello, Campinas. Ela foi estocada conforme o esquema abaixo. (Figura 5)

Cultura de lactobacilos liofilizada

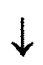

Reativação (em $5 \mathrm{~mL}$ de meio de cultivo líquido MRS)

$$
35^{\circ} \mathrm{C} \pm 1^{\circ} \mathrm{C} \text { por } 24 \text { horas }
$$

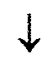

Repicagem (em $5 \mathrm{~mL}$ de meio de cultivo líquido MRS)

$$
35^{\circ} \mathrm{C} \pm 1^{\circ} \mathrm{C} \text { por } 24 \text { horas }
$$

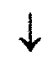

Dessa cultura retirou-se $0,6 \mathrm{~mL}$ que foram inoculados em $4 \mathrm{~mL}$ de leite em pó desnatado 9\% P/V esterilizado

$$
\text { Congelamento da solução de bactérias em leite desnatado }
$$

Figura 5 - Esquema de estocagem das bactérias 
A cultura estoque foi crescida em meio MRS (conforme a figura 6) até volume de $200 \mathrm{~mL}$, sendo que a biomassa bacteriana foi obtida por centrifugação $(800 \times \mathrm{x}$ por 40 minutos).

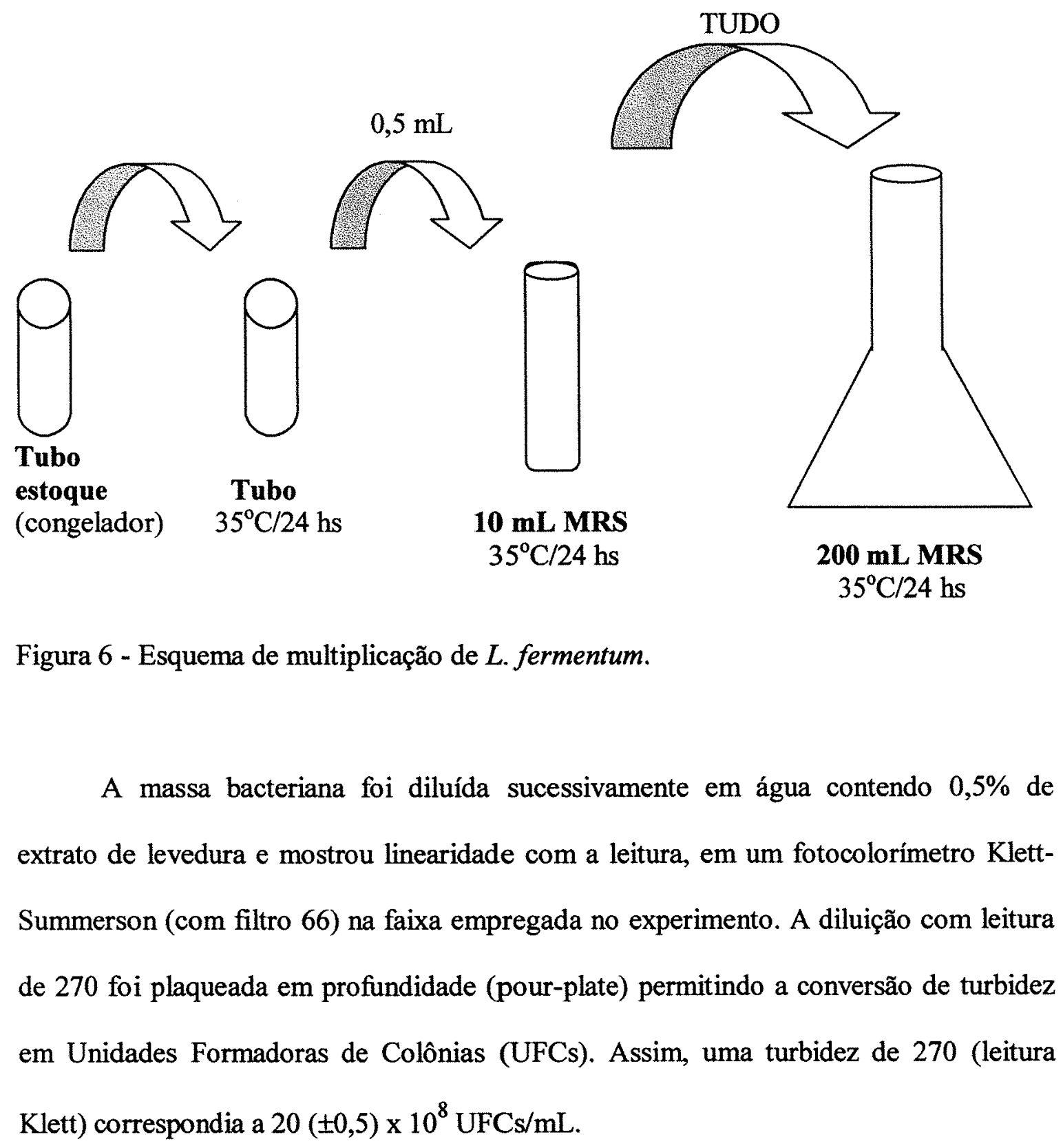




\subsubsection{Curva de crescimento de lactobacilos no vinho de diferentes leveduras}

- Leveduras: Foram utilizadas cinco diferentes linhagens de leveduras Saccharomyces cerevisiae: PE-2, BG-1, CAT-1, IZ-1904 e FLE (Fleischmann de panificação).

- Multiplicação das leveduras: Foi inicialmente realizada em tubos com $10 \mathrm{~mL}$ de meio YEPD a partir de culturas estoques, e posteriormente propagada em $40 \mathrm{~mL}$ de meio YEPD. O crescimento anaeróbico continuou à temperatura ambiente $\left(23 \pm 2^{\circ}\right.$ C), em frascos do tipo erlenmeyers com $500 \mathrm{~mL}$ de meio de melaço com $6 \%$ de ART, suplementado com $\mathrm{KH}_{2} \mathrm{PO}_{4}(0.87 \mathrm{~g} / \mathrm{L}),\left(\mathrm{NH}_{4}\right)_{2} \mathrm{SO}_{4}(0.66 \mathrm{~g} / \mathrm{L})$, uréia $(0.66$ $\mathrm{g} / \mathrm{L}), \mathrm{MgSO}_{4} \cdot \mathrm{H}_{2} \mathrm{O}(0.49 \mathrm{~g} / \mathrm{L}), \mathrm{ZnSO}_{4} \cdot 7 \mathrm{H}_{2} \mathrm{O}(0.03 \mathrm{~g} / \mathrm{L}), \mathrm{MnSO}_{4} \cdot \mathrm{H}_{2} \mathrm{O}(0.02 \mathrm{~g} / \mathrm{L})$ e ácido linolêico $(0.03 \mathrm{~g} / \mathrm{L})$. (figura 7$)$
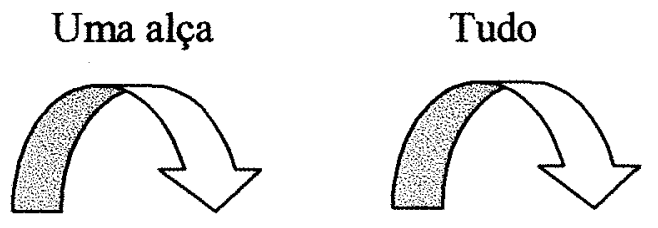

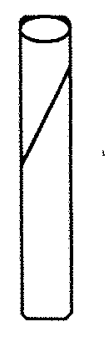

Tubo Inclinado

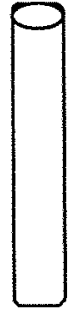

$10 \mathrm{~mL}$

YEPD

24 horas

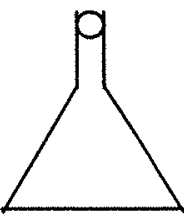

$40 \mathrm{~mL}$ YEPD 24 horas
Tudo
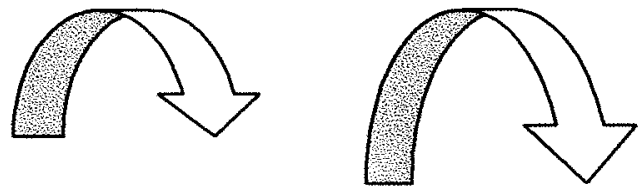

centrifugação ( $800 \times$ G por 20 minutos) e utilização do vinho

Figura 7 - Esquema da obtenção do vinho de diferentes leveduras utilizado para a avaliação do crescimento de L. fermentum. 
3.3.3 Meio de crescimento: Após o término de crescimento das diferentes leveduras, os respectivos vinhos delevedurados (obtidos por centrifugação a 800 x G por 20 minutos) foram ajustados para $\mathrm{pH} 5,0$ e teor de álcool (3,26\% no primeiro experimento e $3,68 \%$ no segundo experimento). A viabilidade da levedura, assim como os teores de glicerol, glicose, frutose e sacarose residuais eram aproximadamente iguais, razão pela qual não foram ajustados. Após análises prévias, todos os vinhos foram suplementados com 1\% de glicose e $0,5 \%$ de extrato de levedura. Foram preparados 3 diferentes meios de crescimento (figura 8 ), todos com $1 \%$ de glicose e $0,5 \%$ de extrato de levedura e ajustados para um $\mathrm{pH}$ final de 5,0.

Para tal, a glicose e o extrato de levedura foram dissolvidos em vinho (meio V), em vinho e água na proporção de 1:1 (meio AV) e em água (meio A), conforme a figura 8.

\section{MEIO YED (1\% DE GLICOSE E 0,5\% DE EXTRATO DE LEVEDURA) EM:}

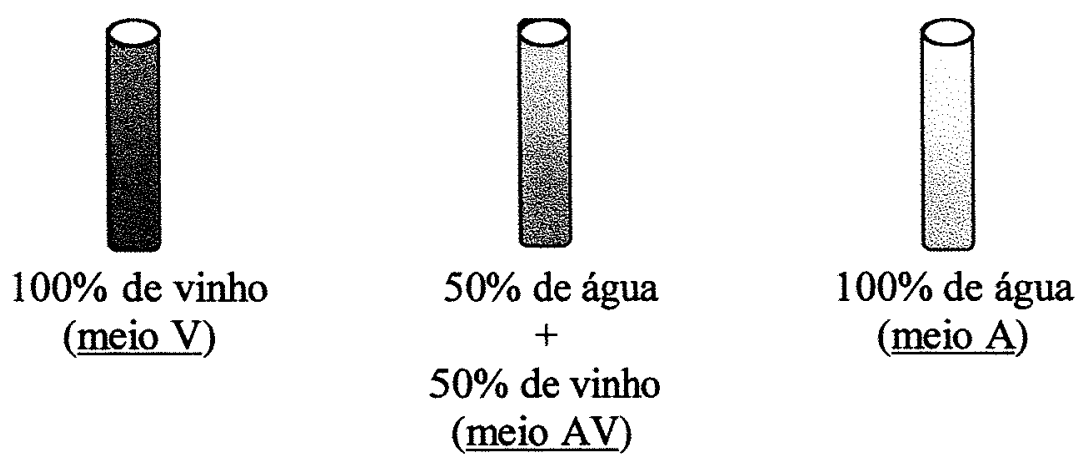

Figura 8 - Meios de crescimento da bactéria L. fermentum. 
- Bactéria: Foi utilizada a bactéria Lactobacillus fermentum (CCT 1407) não floculante.

- Multiplicação da bactéria: Foi feita conforme a figura 9.

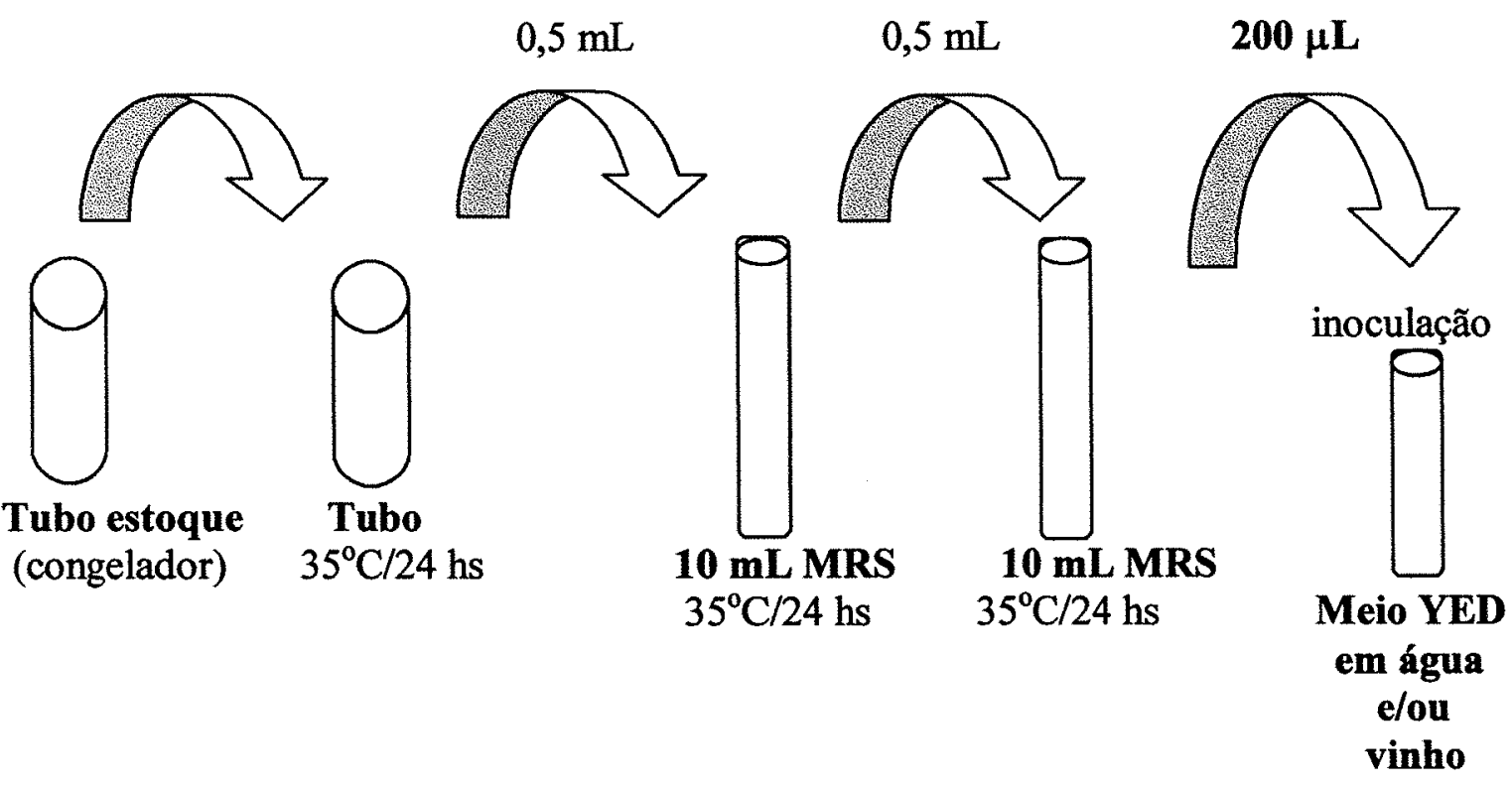

Figura 9 - Esquema de multiplicação da bactéria.

- Inoculação: Após a multiplicação das bactérias a suspensão foi homogeneizada e então $200 \mu \mathrm{L}$ da suspensão foram inoculados em tubos de ensaio contendo $5 \mathrm{~mL}$ de meio YED esterilizado e incubados a $35^{\circ} \mathrm{C}$. As leituras da turbidez foram efetuadas nos tempos $0,2,4,6,8,10,12,24,26,28,30$, e 32 horas empregando-se um fotocolorímetro Klett-Summerson (filtro $\mathrm{n}^{0}$ 66), com as quais se construiu as curvas de crescimento do Lactobacillus. 


\section{EXPERIMENTO 3:}

\subsection{Ensaio de fermentação}

3.4.1 Leveduras: Foram utilizadas quatro diferentes linhagens de leveduras Saccharomyces cerevisiae: PE-2, BG-1, FLE e IZ-1904.

3.4.2 Multiplicação das leveduras: Foram realizadas em meio YEPD a partir de culturas puras (liofilizadas) e propagada anaerobicamente, a $30^{\circ} \mathrm{C}$, em meio de melaço com $6 \%$ de ART, suplementado com sais. Tal meio, previamente esterilizado $\left(120^{\circ} \mathrm{C}, 1\right.$ atm, por 20 minutos), foi adicionado à suspensão de levedura de modo a duplicar o volume a cada dia. Uma vez obtida a biomassa de levedura necessária para o ensaio, a mesma foi seperada do meio mediante centrifugação ( $800 \mathrm{X} \mathrm{G}$, por 20 minutos) e transferida para os frascos de fermentação.

3.4.3 Bactéria: Foi utilizada a bactéria Lactobacillus fermentum (CCT 1407) não floculante.

3.4.4 Multiplicação das bactérias: Foi realizada a partir de uma cultura estoque, propagada em meio MRS. Após a obtenção da quantidade de biomassa necessária o meio foi centrifugado ( $800 \times$ G por 40 minutos) e a biomassa utilizada nos ensaios fermentativos.

3.4.5 Meio de fermentação: Os meios fermentativos foram preparados com teores de ART de 193 g.L $\mathrm{L}^{-1}$, sendo que $70 \%$ do açúcar foi oriundo de caldo de cana e $30 \%$ oriundo do melaço. 
3.4.6 Ensaio de fermentação: Os experimentos foram realizados em tubos de centrífuga com capacidade para $150 \mathrm{~mL}$. Os ensaios foram feitos utilizando-se leveduras e bactérias em co-cultura para a avaliação das interações tróficas existentes entre ambas. Foram feitos quatro tratamentos (utilizadando-se quatro diferentes leveduras: PE-2, BG1, FLE e IZ), todas em co-cultura com lactobacilos. Para cada levedura foram feitas três repetições perfazendo um total de 12 parcelas.

Para o início da fermentação foram adicionados ao tubo $20 \mathrm{~mL}$ de água esterilizada, leveduras ( 7 gramas de massa centrifugada) e bactérias $\left(1,056 \times 10^{8}\right.$ bactérias $/ \mathrm{mL}$ de meio fermentativo [mosto + água + células]). Após isso, foi adicionado $60 \mathrm{~mL}$ do meio fermentativo (preparado com caldo de cana e melaço esterilizados). Esses tubos foram tampados com folha de alumínio e incubados a $33^{\circ} \mathrm{C} \pm 1^{\circ} \mathrm{C}$.

Após o término da fermentação a suspensão era homogeneizada e dela era retirada uma amostra $(0,5 \mathrm{~mL})$ para contagem de bactérias e leveduras e para análise de viabilidade e do brotamento, segundo protocolo de Amorim et al., 1989. Após isso esse vinho bruto era centrifugado para a separação das células (precipitado) e do sobrenadante que era então utilizado para determinação do $\mathrm{pH}$, da concentração de etanol (Zago et al, 1989), de açúcares residuais (AR) e glicerol. As células, por sua vez, eram utilizadas no ciclo fermentativo subsequente após serem pesadas, suspensas em água esterilizada e tratadas com ácido $\left(\mathrm{H}_{2} \mathrm{SO}_{4}\right.$ até $\mathrm{pH}=2,5$ e repouso por 1 hora). Foram também dosados os teores de glicogênio (segundo, Parrou \& Francois, 1997) e trealose (segundo, Trevelyan \& Harrison, 1956a, 1956b e Brin, 1966) nas leveduras antes de iniciar a fermentação e ao final do $10^{\circ}$ ciclo, para se avaliar o estresse imposto às 
leveduras nas condições do ensaio. Foi realizada também a contagem de bactérias através de plaqueamento em profundidade "pour-plate", do inóculo e de todos os tratamentos do ciclo 7 (os quais foram plaqueados em meio de cultura adicionado de actidiona [com uma concentração final de $10 \mathrm{ppm}$ ]). $\mathrm{O}$ rendimento fermentativo foi calculado considerando-se que $100 \mathrm{~g}$ de ART produz $51,11 \mathrm{~g}$ de etanol absoluto, levando-se em conta o etanol produzido na fermentação anterior. $O$ experimento constou de 10 ciclos fermentativos, sendo um ciclo por dia, onde se procurou simular condições industriais.

3.4.7 Análise estatística: Para análise estatística foi utilizado o Sistema de Análise Estatística (SANEST) dos autores Elio Paulo Zonta e Amauri Almeida Machado, sendo o delineamento experimental inteiramente casualisado com parcelas subdivididas, considerando as leveduras como tratamento principal e os ciclos fermentativos como parcelas. Para a análise da variância com testes para os níveis de fatores foi escolhido o Teste de Tukey. 


\section{RESULTADOS E DISCUSSÃO}

\section{EXPERIMENTO 1:}

\subsection{Análise da invertase excretada no meio e do espaço periplasmático de diferentes}

leveduras. Os quadros 1 a 4 contém os resultados encontrados, embora a atividade de invertase tenha variado em função dos horários e dos meios, tanto a invertase periplasmática como a externa mostram grande correspondência em relação às leveduras. Pode-se, assim, concluir que, em ordem crescente, a atividade de invertase das leveduras estudadas é a seguinte: CAT-1, PE-2, BG-1, IZ-1904 e FLE. As atividades enzimáticas apresentadas pelas leveduras FLE e IZ-1904 são sempre superiores aquelas mostradas pelas leveduras CAT-1 e PE-2.

Comparando-se os dados dos quadros 1 e 2 se observa que o meio com melaço (mosto misto) propiciou maior excreção de invertase, para todas as leveduras. Igualmente se observa que o envelhecimento do meio (quadros 1 e 2) assim como o envelhecimento das células (quadro 3 e 4) promovem reduções nas atividades enzimáticas (externa e periplasmática). Neste particular é bastante notória a redução drástica na atividade de invertase periplasmática da levedura IZ-1904 (quadro 3 e 4).

A atividade de invertase externa se mostrou bem mais elevada que a periplasmática para todas as leveduras (quadros 3 e 4), embora tal observação esbarre na 
dificuldade de se comparar análises efetuadas em tempos diferentes ( 70 horas para a externa e 130 horas para a periplasmática).

\begin{tabular}{|l|l|l|l|l|}
\hline LEVEDURASLHORAS & 66 HORAS & 70 HORAS & 90 HORAS & 94 HORAS \\
\hline PE-2 & 49,33 & 38,36 & 41,15 & 30,50 \\
\hline BG-1 & 51,11 & 55,25 & 55,91 & 34,47 \\
\hline FLE & 82,87 & 63,40 & 61,56 & 45,18 \\
\hline IZ & 53,73 & 56,25 & 66,20 & 46,93 \\
\hline CAT & 42,87 & 29,72 & 30,88 & 20,34 \\
\hline
\end{tabular}

Quadro 1 - Atividade de invertase excretada no meio $\left(\mathrm{em} \mu \mathrm{g} \mathrm{AR} \cdot \mathrm{h}^{-1} \cdot \mathrm{mg} \mathrm{lev}{ }^{-1}\right)$ de leveduras crescidas em meio de caldo de cana.

\begin{tabular}{|l|l|l|l|l|}
\hline LEVEDURASLHORAS & 66 HORAS & 70 HORAS & 90 HORAS & 94 HORAS \\
\hline PE-2 & 144,39 & 70,64 & 62,82 & 58,27 \\
\hline BG-1 & 155,62 & 101,93 & 94,12 & 91,74 \\
\hline FLE & 178,04 & 137,84 & 162,13 & 131,35 \\
\hline IZ & 158,32 & 106,41 & 119,66 & 108,95 \\
\hline CAT & -- & 58,61 & 58,61 & 45,64 \\
\hline
\end{tabular}

Quadro 2 - Atividade de invertase excretada no meio $\left(\mathrm{em} \mu \mathrm{g} \mathrm{AR} \cdot \mathrm{h}^{-1} \cdot \mathrm{mg} \mathrm{lev} v^{-1}\right)$ de leveduras crescidas em mosto misto (caldo + melaço).

\begin{tabular}{|l|l|l|l|}
\hline \multicolumn{1}{|c|}{ LEVEDURAS } & $\begin{array}{c}\text { INVERTASE } \\
\text { EXTRACELULAR } \\
\text { (70 HORAS) }\end{array}$ & $\begin{array}{c}\text { INVERTASE } \\
\text { PERIPLASMÁTI- } \\
\text { CA (130 HORAS) }\end{array}$ & $\begin{array}{c}\text { INVERTASE } \\
\text { PERIPLASMÁTI- } \\
\text { CA (178 HORAS) }\end{array}$ \\
\hline PE-2 & 121,97 & 45,66 & 54,75 \\
\hline BG-1 & 139,15 & 67,95 & 66,48 \\
\hline FLE & 372,72 & 123,63 & 116,31 \\
\hline IZ & 273,28 & 6,66 & 18,15 \\
\hline CAT & 98,43 & 38,97 & 56,16 \\
\hline
\end{tabular}

Quadro 3 - Primeiro experimento de determinação da atividade de invertase (em $\mu \mathrm{g}$ AR. $\mathrm{h}^{-1} \cdot \mathrm{mg} \mathrm{lev} \mathrm{v}^{-1}$ ) do espaço periplasmático de leveduras crescidas em meio de melaço com $6 \%$ de ART. 


\begin{tabular}{|l|l|l|l|}
\hline \multicolumn{1}{|c|}{ LEVEDURAS } & $\begin{array}{c}\text { INVERTASE } \\
\text { EXTRACELULAR } \\
\text { (70 HORAS) }\end{array}$ & $\begin{array}{c}\text { INVERTASE } \\
\text { PERIPLASMÁTI- } \\
\text { CA (130 HORAS) }\end{array}$ & $\begin{array}{c}\text { INVERTASE } \\
\text { PERIPLASMÁTI- } \\
\text { CA (178 HORAS) }\end{array}$ \\
\hline PE-2 & 104,86 & 43,26 & 34,44 \\
\hline BG-1 & 150,46 & 46,20 & 30,30 \\
\hline FLE & 334,80 & 70,80 & 54,15 \\
\hline IZ & 260,36 & 3,93 & 0,14 \\
\hline CAT & 106,36 & 38,34 & 25,80 \\
\hline
\end{tabular}

Quadro 4 - Segundo experimento (semelhante ao primeiro) de determinação da atividade de invertase (em $\mu \mathrm{g} \mathrm{AR} . \mathrm{h}^{-1} \cdot \mathrm{mg} \mathrm{lev}^{-1}$ ) do espaço periplasmático de leveduras crescidas em meio de melaço com $6 \%$ de ART.

Os dados encontrados nesse trabalho estão de acordo com Laluce et al. (1991) que concluíram que a atividade de invertase é diferente entre diferentes linhagens. Alves (2000) observou elevada atividade de invertase para a levedura Fleischmann em comparação com a PE-2, sugerindo que a velocidade com que a sacarose é hidrolisada é superior àquela com que os monossacarídeos são metabolizados. Tal descompasso leva à um acúmulo de glicose e frutose, resultando num estresse osmótico mais intenso para a levedura Fleischmann.

Pode-se especular que a alta atividade de invertase das leveduras FLE e IZ-1904 possam colaborar para a sua baixa capacidade de sobrevivência em fermentações industriais com reciclos, pois que acabe resultando em um estresse osmótico. 


\section{EXPERIMENTO 2}

\subsection{Crescimento de lactobacilos nos vinhos de diferentes leveduras}

Esse experimento teve como objetivo estudar se algum fator presente no vinho de alguma linhagem de levedura pudesse inibir ou estimular o crescimento do lactobacilo, mascarando a influência da atividade de invertase em condições de fermentação mista. Assim, como os vinhos foram previamente esterilizados, a invertase foi desnaturada, de sorte que se pode avaliar se existe diferenças entre as leveduras no tocante a outros componentes do vinho que possam afetar o crescimento bacteriano.

Os dados obtidos mostram que o crescimento bacteriano foi semelhante para todas as leveduras (figuras 10 e 11) podendo-se concluir que os vinhos das leveduras estudadas não apresentam diferenças quanto ao estímulo ou repressão ao crescimento bacteriano.

No entanto é observado um efeito depressivo do vinho sobre o crescimento bacteriano manifestado manifestado por todas as leveduras, porém, como dito, sem diferenças entre as leveduras. Já foi documentada a ação antibacteriana da própria fermentação, exercida pelo ácido succínico em ação sinérgica com o etanol (Basso et al., 1997), ambos produzidos pela levedura durante a fermentação. 

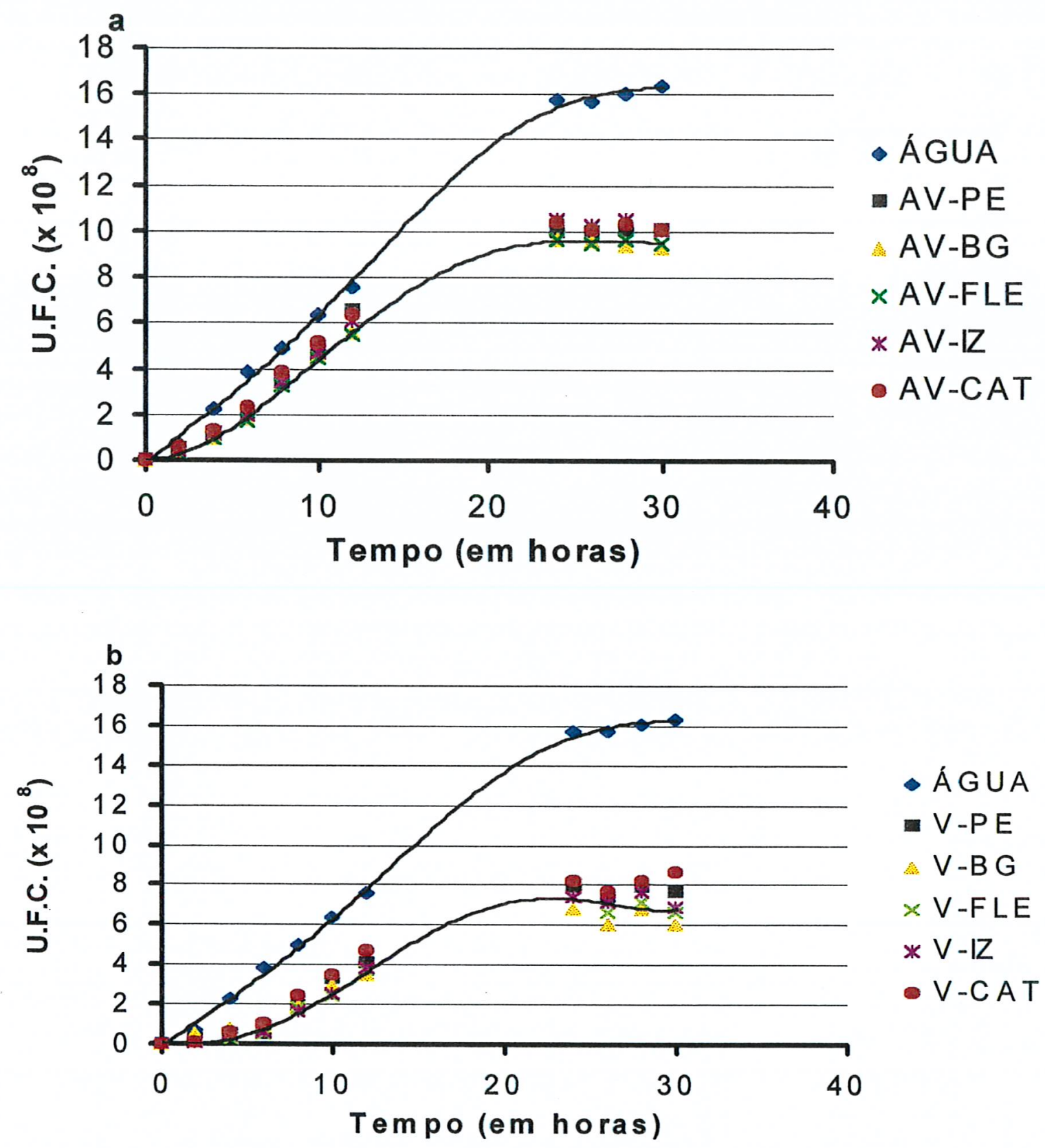

Figura 10 - Curva de crescimento de L. fermentum em meios YED (0,5\% de extrato de levedura $+1 \%$ de glicose) em água (ÁGUA) e água e vinho (1:1) (AV) (a) e em água (ÁGUA) e vinho (V) (b). Foram utilizados os vinhos de multiplicação de cinco leveduras: PE, BG, FLE, IZ e CAT. (Primeiro experimento $=$ vinho de melaço A). Os dados dessas curvas encontram-se no apêndice (quadros 1 e 2). 

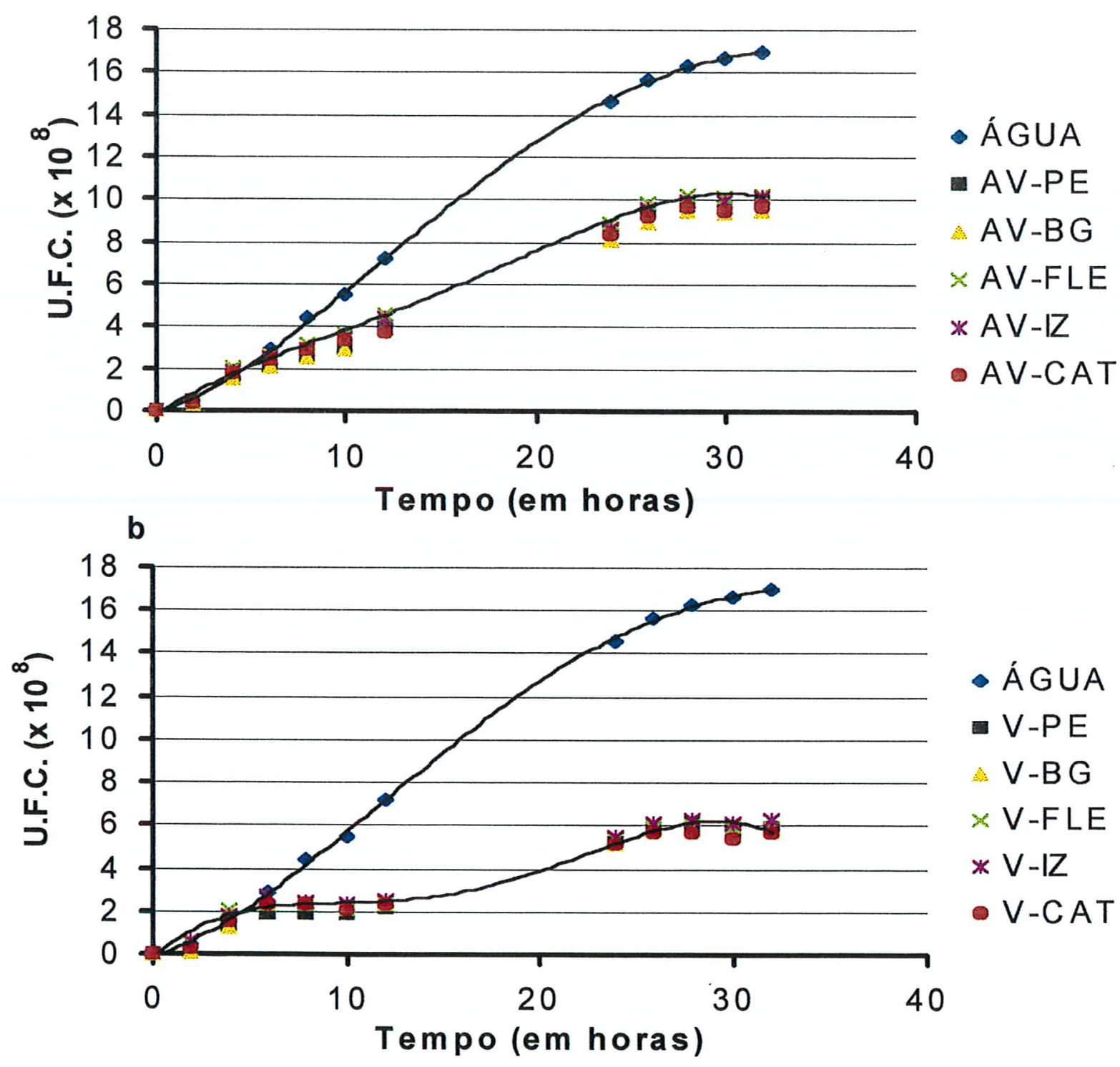

Figura 11 - Curva de crescimento de L. fermentum em meios YED (0,5\% de extrato de levedura $+1 \%$ de glicose) em água (ÁGUA) e água e vinho (1:1) (AV) (a) e em água (ÁGUA) e vinho (V) (b). Foram utilizados os vinhos de multiplicação de cinco leveduras: PE, BG, FLE, IZ e CAT. (Segundo experimento $=$ vinho de melaço B). Os dados dessas curvas encontram-se no apêndice (quadros 3 e 4). 


\section{EXPERIMENTO 3:}

\subsection{Ensaio de fermentação}

As leveduras PE-2, BG-1, FLE e IZ-1904 foram submetidas a fermentações em presença de Lactobacillus fermentum, buscando-se avaliar a interação entre esses microrganismos em condições de fermentação. Nas figuras 12, 13, 14 e 15 são apresentados os valores de $\mathrm{pH}$ final do vinho, viabilidade da levedura, contaminação bacteriana, rendimento em etanol, peso de fermento, taxa de brotamento da levedura e teor de etanol nos vinhos, no transcorrer de 10 ciclos fermentativos. Os valores, juntamente com a análise estatística se encontram no apêndice. A contagem de bactérias através de plaqueamento em profundidade "pour-plate" em meio de cultura MRS adicionado de actidiona encontra-se no quadro 5. Os teores de trealose e glicogênio celular das diferentes linhagens antes e após os 10 ciclos fermentativos encontra-se no quadro 6. 

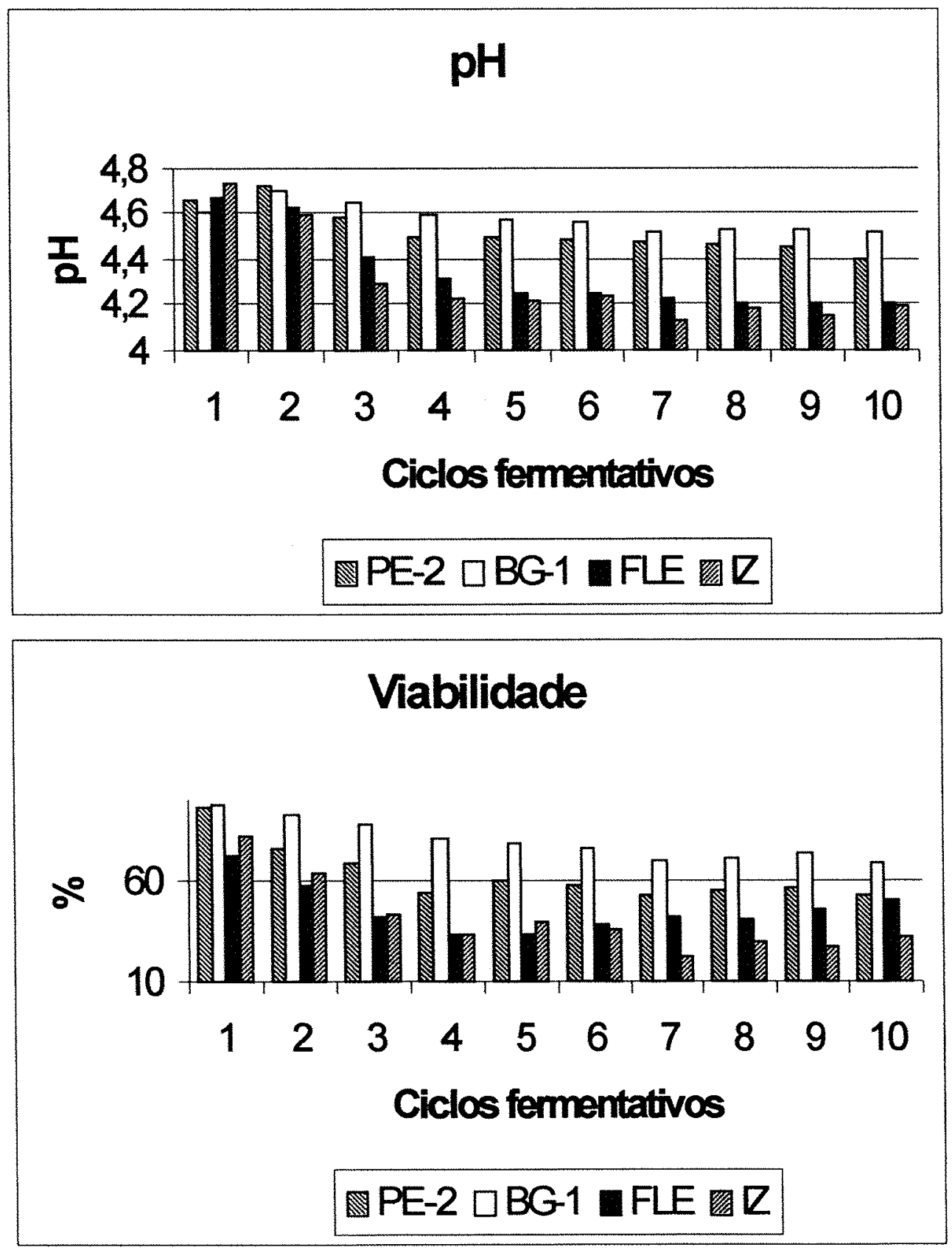

Figura 12 - Efeito de diferentes leveduras em co-cultura com lactobacilos ao longo de 10 ciclos fermentativos sobre o $\mathrm{pH}$ dos vinhos e viabilidade das leveduras. 

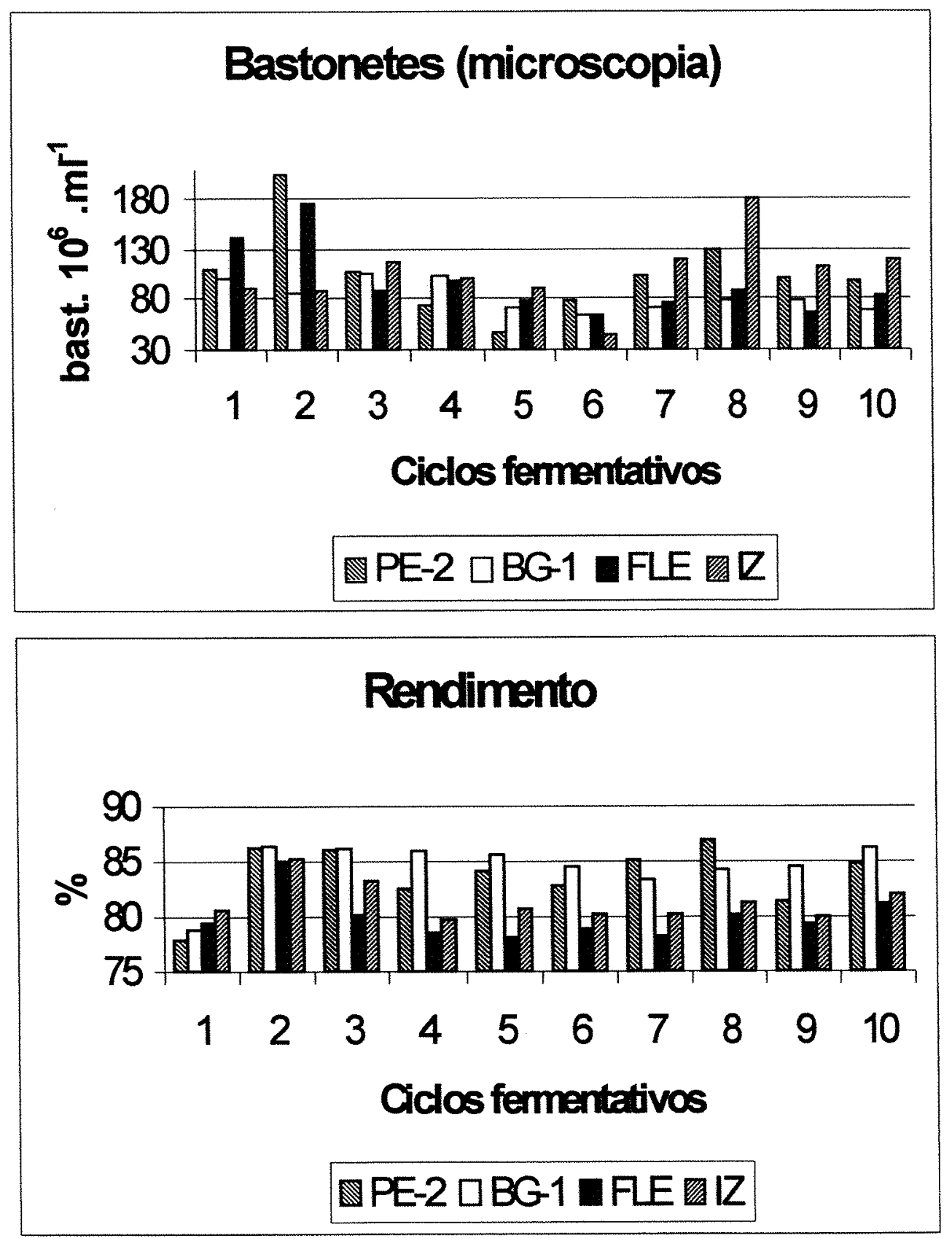

Figura 13 - Efeito de diferentes leveduras em co-cultura com lactobacilos ao longo de 10 ciclos fermentativos sobre a contaminação bacteriana (contagem ao microscópio) e rendimento. 

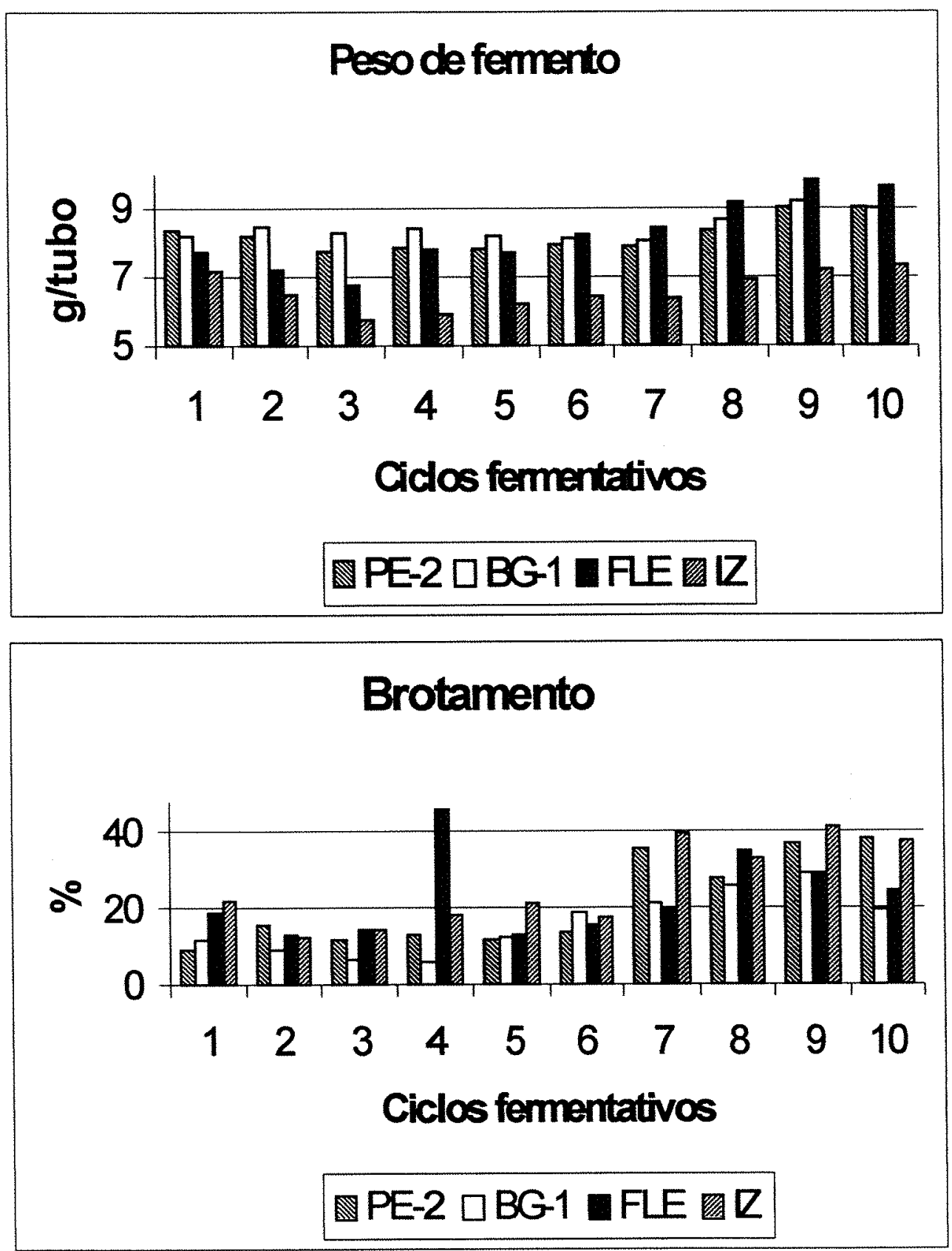

Figura 14 - Efeito de diferentes leveduras em co-cultura com lactobacilos ao longo de 10 ciclos fermentativos sobre o peso de fermento e taxa de brotamento. 


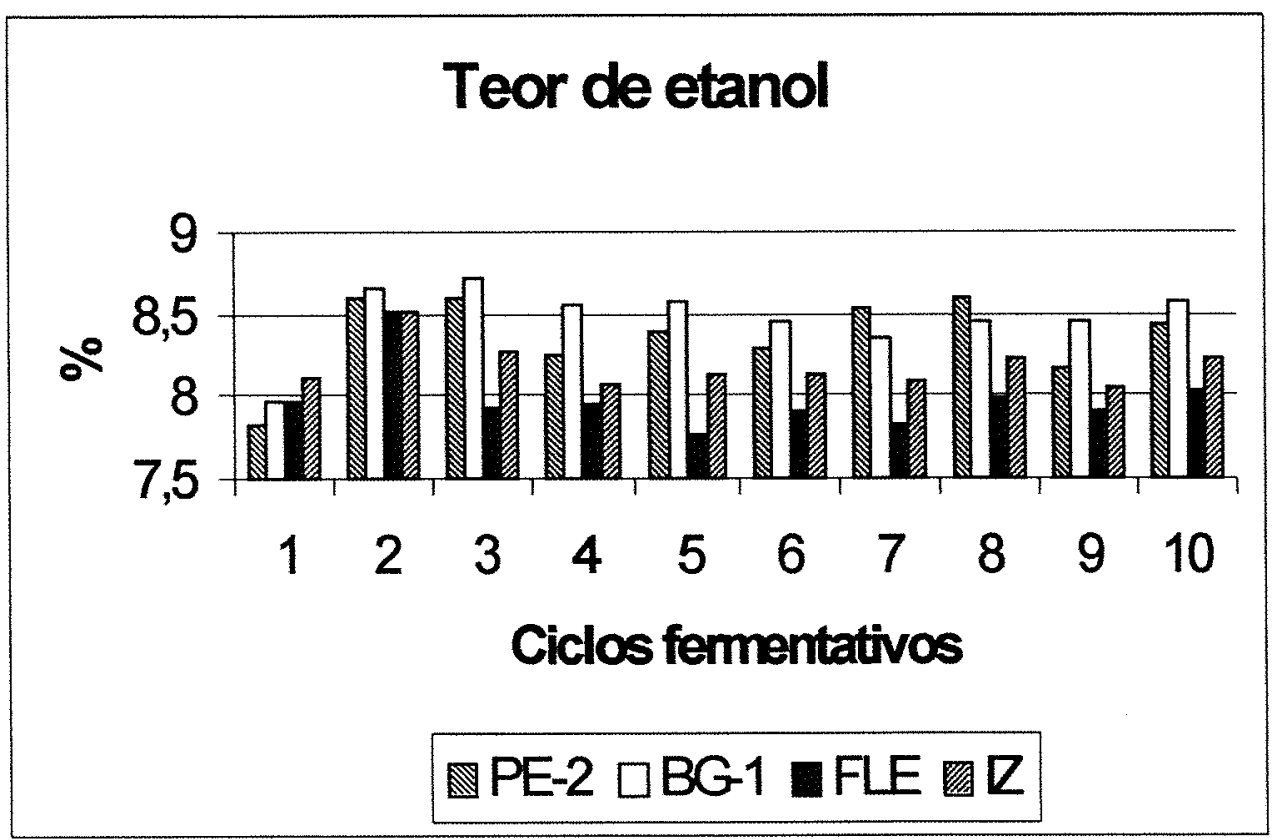

Figura 15 - Efeito de diferentes leveduras em co-cultura com lactobacilos ao longo de 10 ciclos fermentativos sobre o teor de etanol nos vinhos.

\begin{tabular}{|l|l|l|}
\hline LEVEDURA & $\begin{array}{l}\text { CONTAMINAÇÃO } \\
\text { INICIAL }\end{array}$ & $7^{\circ}$ CICLO \\
\hline PE-2 & $1,056( \pm 0,061) \times 10^{8}$ & $2,29( \pm 0,520) \times 10^{8}$ \\
\hline BG-1 & $1,056( \pm 0,061) \times 10^{8}$ & $1,28( \pm 0,123) \times 10^{8}$ \\
\hline FLE & $1,056( \pm 0,061) \times 10^{8}$ & $3,28( \pm 0,458) \times 10^{8}$ \\
\hline $\mathrm{IZ}-1904$ & $1,056( \pm 0,061) \times 10^{8}$ & $3,09( \pm 0,268) \times 10^{8}$ \\
\hline
\end{tabular}

Quadro 5 - Contagem de bactérias através de plaqueamento em profundidade "pourplate" em meio de cultura MRS adicionado de actidiona tanto no primeiro ciclo como no vinho do sétimo ciclo fermentativo. 


\begin{tabular}{|l|c|c|c|c|}
\hline \multirow{2}{*}{ LEVEDURA } & \multicolumn{2}{|c|}{ GLICOGENNIO (\%) } & \multicolumn{2}{c|}{ TREALOSE (\%) } \\
\cline { 2 - 5 } & INICIAL & FINAL & INICIAL & FINAL \\
\hline PE-2 & $\mathbf{6 , 8}$ & $\mathbf{1 8 , 9}$ & $\mathbf{2 , 8}$ & $\mathbf{3 , 0}$ \\
\hline BG-1 & $\mathbf{4 , 3}$ & $\mathbf{1 1 , 7}$ & $\mathbf{1 , 4}$ & $\mathbf{3 , 3}$ \\
\hline FLE & $\mathbf{1 1 , 9}$ & $\mathbf{2 8 , 9}$ & $\mathbf{3 , 9}$ & $\mathbf{3 , 5}$ \\
\hline IZ - 1904 & $\mathbf{4 , 7}$ & $\mathbf{7 , 6}$ & $\mathbf{2 , 5}$ & $\mathbf{2 , 1}$ \\
\hline
\end{tabular}

Quadro 6 - Teores celulares de trealose e glicogênio (\% na matéria seca) nas diferentes linhagens de leveduras antes do ensaio e após o $10^{\circ}$ ciclo fermentativo.

$\mathrm{O}$ rendimento em etanol se apresentou mais elevado para as leveduras PE-2 e BG-1 quando comparado com a FLE e IZ-1904 (P < 0,05). Simultaneamente o crescimento da IZ-1904 foi menor durante o transcorrer do experimento $(P<0,05)$. Já foi constatada a vulnerabilidade da levedura IZ-1904 quando submetida a reciclos, demonstrada pelo baixo crescimento, menor viabilidade e dificuldade de manutenção de teores adequados de trealose e glicogênio, quando comparada com as leveduras FLE e TA (M-300A) (Basso et al., 1988). Os resultados apresentados igualmente demonstram reduções na viabilidade e nos teores dos carboidratos de reserva (trealose) e menor acúmulo relativo de glicogênio quando a levedura IZ-1904 foi submetida a reciclos.

A rigor, tanto a viabilidade da IZ-1904 como da FLE se apresentaram menores quando comparadas com as leveduras PE-2 e BG-1. Tais resultados podem ser interpretados à luz da constatação que as leveduras IZ-1904 e FLE apresentam baixa capacidade de sobrevivência em ambiente industrial (Basso et al., 1993) enquanto as leveduras PE-2 e BG-1 são capazes de sobreviver ao longo da safra (200-250 dias) em muitas destilarias (Wheals et al., 1999; Basso e Amorim, 2001; Basso e Amorim, 2000). 
A taxa de brotamento não mostrou tendência definida e não guarda necessariamente relação com o crescimento do fermento e nem com a viabilidade, pois sendo uma medida pontual pode sofrer a crítica de que o broto demora mais ou não se desprende da célula mãe.

A contaminação bacteriana avaliada pela contagem ao microscópio de células tipo bastonete não se mostrou diferenciada para as diferentes linhagens de leveduras. A avaliação dessa contaminação bacteriana pela técnica de "pour-plate", conduzida no vinho do sétimo ciclo fermentativo não guarda correlação com a contagem ao microscópio, que como era de se esperar se mostrou menor. Isto pelo fato de que foram contadas apenas as células tipo bastonete ao microscópio ótico.

A despeito das diferenças entre as atividades de invertase das linhagens estudadas não se observam alterações na magnitude da contaminação bacteriana.

Por outro lado, as quedas mais intensas nas viabilidades celulares das leveduras FLE e IZ-1904, deveriam propiciar um aumento na contaminação bacteriana, não somente pela menor competitividade pelos nutrientes do meio como também pela liberação de fatores para o crescimento bacteriano em virtude da autólise das células de levedura. Está bem documentado na literatura o estímulo ao crescimento bacteriano promovido por determinados aminoácidos, que podem advir da autólise das leveduras. (Oliva-Neto e Yokoya, 1996 e 1997).

No entanto, no presente experimento, as menores viabilidades observadas com as leveduras FLE e IZ-1904 não foram acompanhadas por um aumento na contaminação bacteriana. 
Uma possível explicação para tais observações reside no fato de que o pH final dos vinhos das leveduras FLE e IZ-1904 foram significativamente menores que os valores observados para as leveduras PE-2 e BG-1.

Tais constatações permitem especular sobre as características de cada linhagem em relação à contaminação bacteriana. Assim, menores valores de $\mathrm{pH}$ dos vinhos das leveduras FLE e IZ-1904, podem ser conseqüência de uma maior excreção dos ácidos orgânicos durante a fermentação. Basso et al., (1988) constataram que a excreção de ácido succínico pela levedura IZ-1904 foi $46 \%$ superior àquela apresentada pela levedura FLE, tomando uma média de 6 ciclos fermentativos. Por sua vez, a levedura FLE excreta mais ácidos orgânicos (succínico e málico) que a PE-2 (Alves, 2000). Neste último trabalho se mostrou que os teores de ácido succínico foram $1200 \mathrm{mg} / \mathrm{L}$ para a levedura FLE enquanto a PE-2 apresentou valores de 350 a $700 \mathrm{mg} / \mathrm{L}$ no vinho final. Com relação ao ácido málico, se constatou um pico de excreção de $3200 \mathrm{mg} / \mathrm{L}$ com uma hora de fermentação para a levedura FLE, enquanto a PE-2 mostrou tal pico às duas horas de fermentação e, perceptivelmente menor, ou seja, na ordem de $2200 \mathrm{mg} / \mathrm{L}$. Segundo a autora, essa excreção diferenciada de ácidos orgânicos explicaria os menores valores de $\mathrm{pH}$ dos vinhos finais da levedura FLE $(\mathrm{pH}=3,70)$ em comparação com a PE$2(\mathrm{pH}=4,10)$.

Logicamente o $\mathrm{pH}$ mais baixo durante a fermentação exerceria um efeito repressor sobre o crescimento bacteriano, conforme já documentado (Basso et al., 1997). Embora os teores alcoólicos nos vinhos das leveduras PE-2 e BG-1 se mostrem mais elevados (8,5\%) quando comparados com as leveduras FLE e IZ-1904 (8,0\%), é 
provável que o menor $\mathrm{pH}$ dos vinhos dessas últimas leveduras seja mais relevante no controle da contaminação bacteriana.

Embora do ponto de vista prático a contaminação bacteriana não foi alterada em função das linhagens de leveduras empregadas (em ensaios com reciclos), uma abordagem mais profunda sobre os dados apresentam uma série de dificuldades quanto à sua interpretação. Assim as leveduras FLE e IZ-1904, (em relação às demais) poderiam favorecer a contaminação bacteriana em decorrência das menores viabilidades celulares (autólise) e maiores atividades de invertase, porém exerceriam simultâneamente um efeito repressor mais severo ao crescimento bacteriano devido a uma maior excreção de ácidos orgânicos com conseqüente abaixamento do $\mathrm{pH}$.

Outros experimentos deveriam ser delineados para se isolar cada um desses fatores. 


\section{CONCLUSÕES}

- As leveduras estudadas mostram diferenças quanto à atividade de invertase, que em ordem crescente é a seguinte: CAT-1, PE-2, BG-1, IZ-1904 e FLE.

- A atividade de invertase excretada para o meio externo é maior que aquela localizada no espaço periplasmático e interna.

- Os vinhos das leveduras estudadas mostram um efeito depressivo sobre o crescimento bacteriano, mas sem diferenças para as leveduras estudadas.

- As diferenças nas atividades de invertase não resultaram em alterações nos níveis de contaminação bacteriana em fermentações com reciclo. 


\section{REFERÊNCIAS BIBLIOGRÁFICAS}

ABRAHÃO-NETO, J.; INFANTI, P.; VITOLO, M. Influence of $\mathrm{pH}$, temperature and dissolved oxygen concentration on the production of glucose 6-phosphate dehydrogenase and invertase by Saccharomyces cerevisiae. Brazilian Journal of Chemical Engineering, v.14, n.1, p.3-10, Mar. 1997.

AKSU, Z.; KUTSAL, S. Lactic acid production from molasses utilizing Lactobacillus delbrueckii and invertase together. Biotechnology Letters, v.8, n.3, p.157-160, 1986.

ALEXANDER, M. Microbial Ecology. London: John Wiley \& Sons, 1971. 511p.

ALTERTHUM, F.; MELO CRUZ, M.R.; RIBEIRO VAIRO, M.L.; GAMBASSI, D.M. Efeito dos microrganismos contaminantes da fermentação alcoólica nas microdestilarias. STAB, p.42-49, set/out. 1984. 
ALVES, D.M.G. Respostas fisiológicas de duas linhagens de Saccharomyces Cerevisiae frente ao potássio durante a fermentação alcoólica. Rio Claro, 2000. 118p. Tese (Doutorado) - Instituto de Biociências de Rio Claro, Universidade Estadual Paulista "Julio de Mesquita Filho".

AMORIM, H.V.; OLIVEIRA, A.J. Infecção na fermentação: como evitá-la. Alcool \& Açúcar, n.5, p.12-18, 1982.

AMORIM, H.V.; OLIVEIRA, A.J.; ZAGO, E.A.; BASSO, L.C.; GALLO, C.R. Processos de fermentação alcoólica, seu controle e monitoramento. Piracicaba: Fermentec, 1989. 145p.

AQUARONE, E. Penicillium and tetracycline as control agents in alcoholic fermentation of sugar cane molasses. Applied Microbiology, v.8, p.263-268, 1960.

ASHMAN, D.F.; MARQUEZ, M.P.E.; VILLOALOBOS, C.H. Guia de trabajos practicos de bioquímica. Maracaibo: Papelera Comercia C. A., 1960. 169p.

BACILA, M. Curso de fisiologia de microrganismo. Curitiba: UFRP, Instituto de Química, 1960. 209p.

BARBOUR, E.A.; PRIEST, F.G. Some effects of Lactobacillus contamination in scotch whisky fermentations. Journal of the Institute of Brewing, v.94, p.89-92, 1988. 
BASSO, L.C.; ALVES, D.M.G.; AMORIM, H.V. The antibacterial action of succinic acid produced by yeast during fermentation. Revista de Microbiologia, v.28, p.7782, 1997. Supplement 1.

BASSO, L.C.; AMORIM, H.V. Industrial ethanol in Brazil: biotechnological advances. In: INTERNATIONAL ALCOHOL PRODUCTION WORKSHOP, 3., Cuba, 2001. Anais. p. 35-36.

BASSO, L.C.; AMORIM, H.V. Seleção de leveduras para a fermentação alcoólica (compact disc). In: SIMPÓSIO NACIONAL DE FERMENTAÇÕES, 8., Teresópolis, 2000. Trabalhos. Teresópolis: UFRJ - COPPE, 2000.

BASSO, L.C.; AMORIM, H.V.; GUTIERREZ, L.E. Estudo comparativo entre os fermentos Fleishmann, IZ-1904 e M-300 A (TA). Relatório Anual de Pesquisas em Fermentação Alcoólica, n.8, p. 34-43, 1988.

BASSO, L.C.; OLIVEIRA, A.J.; ORELLI, V.F.D.M.; CAMPOS, A.A.; GALLO, C.R. E AMORIM, H.V. Dominância das leveduras contaminantes sobre as linhagens industriais avaliada pela técnica de cariotipagem. In: CONGRESSO NACIONAL DA STAB, 5., São Paulo, 1993. Anais. p. 246-250. 
BOKASSA, I.P.; KRASTANOV, A.I.; ROCHKOVA, Z.; ANGELOV, A. Biosynthesis of invertase by Saccharomyces cerevisiae with sugarcane molasses as substrate. World Journal of Microbiology and Biotechnology, v.9, p.662-663, 1993.

BOLETIM TÉCNICO COPERSUCAR. Controle microbiológico da Usina de Açúcar e Álcool, n.22, p.2-17, maio 1983.

BORZANI, W. Control of contamination level in repeated batch ethanol fermentation of unsterilized molasses media. Biotechnology Letters, v.8, p.187-190, 1986.

BRIN, M. Transketalose: clinical aspects. Methods in Enzimology, v.9, p.606-614, 1966.

BUCKER JR., E.R.; MITCHELL JR., J.H.; JOHNSON, M.G. Lactic fermentation of peanut milk. Journal of Food Science, v.44, p.1534-1538, 1979.

CHALLINOR, S.W.; ROSE, A.H. Inter-relationships between yeast and bacterium when growing together in a defined medium. Nature, v.174, p.877-878, 1954.

CHASSY, B.M.; THOMPSON, J. Regulation and characterization of the galactosephosphoenolpyruvate-dependent phosphotransferase system in Lactobacillus casei. Journal of Bacteriology, v.154, n.3, p.1204-1214, 1983. 
CHIN, P.M.; INGLEDEW, W.M. Effect of lactic acid bacteria on wheat mash fermentations prepared with laboratory backset. Enzyme and Microbial Technology, v.16, p.311-317, 1994.

DAHIYA, R.S.; SPECK, M.L. Hydrogen peroxide formation by lactobacilli and its effect on Staphylococcus aureus. Journal of Dairy Science, v.51, p.1568-1572, 1968.

DOLAN, T.C.S. Bacteria in whisky production. Brewer, v.65, p.60-64, 1979.

ESSIA NGANG, J.J.; LETOURNEAU, F.; VILLA, P. Alcoholic fermentation of beet molasses: effects of lactic acid on yeast fermentation parameters. Applied Microbiology and Bioengineering, v.31, p.125-128, 1989.

ESSIA NGANG, J.J.; LETOURNEAU, F.; WOLNIEWICZ, E.; VILLA, P. Inhibition of beet molasses alcoholic fermentation by lactobacilli. Applied Microbiology and Bioengineering, v.33, p.490-493, 1990.

ESSIA NGANG, J.J.; WOLNIEWICZ, E.; LETOURNEAU, F. VILLA, P. Stimulation of lactobacilli during alcoholic fermentation: action of sucrose hydrolysis by yeast. Biotechnology Letters, v.14, n.8, p.741-746, Aug. 1992. 
GALLO, C.R. Determinação da microbiota bacteriana de mosto e de dornas de fermentação alcoólica. Campinas, 1990, 388p. Tese (Doutorado) - Faculdade de Engenharia de Alimentos, Universidade Estadual de Campinas.

GALLO, C. R.; CANHOS, V.P. Contaminantes bacterianos na fermentação alcoólica revisão. STAB, p.35-40, mar/jun. 1991.

GASCÓN, S.; NEUMANN, N.P.; LAMPEN, J.O. Comparative study of the properties of the purified internal and external invertases from yeast. The Journal of Biological Chemistry, v.243, n.7, p.1573-1577, 1968.

GILLILAND, S.E.; SPECK, M.L. Interactions of food starter cultures and food-borne pathogens: lactic streptococci versus Staphylococci and Salmonellae. Journal of Milk and Food Technology, v.35, p.307-310, 1972.

GOBBETTI, M.; CORSETTI, A.; ROSSI, J. The sourdough microflora. Interactions between lactic acid bacteria and yeasts: metabolism of carbohydrates. Applied Microbiology and Biotechnology, v.41, p.456-460, 1994.

HUANG, Y.C.; EDWARDS, C.G.; PETERSON, J.C.; HAAG, K.M. Relationship between sluggish fermentations and the antagonism of yeast by lactic acid bacteria. American Journal of Enology and Viticulture, v.47, p.1-10, 1996. 
INGLEDEW, W.M. Yeasts for the production of fuel ethanol. In: ROSE, A.H.; HARRISON, J.S. (eds.) The Yeasts. London: Academic Press, 1993. p.245-291. v.5: Yeast Technology.

INGLEDEW, W.M. The biochemistry of alcohol production. In: LYONS, T.P.; KELSALL, D.R.; MURTAGH, J.E. (eds.) The alcohol textbook. Nottingham: Nottingham University Press, 1995. p.55-79.

KANDLER, O.; WEISS, N. Regular nonsporing gram positive rods. In: SNEATH, P.H.A.; MAIR, N.S.; SHARPE, M.E.; HOLF, J.G. (eds.) Bergey's Manual of Systematic Bacteriology. Baltimore: Williams and Wilkens, 1986. v.2, p.1208-1234.

KING, S.W.; BEELMAN, R.B. Metabolic interactions between Saccharomyces cerevisiae and Leuconostoc oenos in a model grape juice/wine system. American Journal of Enology and Viticulture, v.37, p.53-60, 1986.

LALUCE, C.; PALMIERI, M.C.; CRUZ, R.C.L. Growth and fermentation characteristics of new selected strains of Saccharomyces at high temperatures and high cell densities. Biotechnology and Bioengineering, v.37, p.528-536, 1991.

LIMA, U de A.; GOLDONI, J.S.; CEREDA, M. P.; SOUZA, L.G. Ocorrência de microrganismos em caldo bruto, caldo misto e água de embebição em uma usina de açúcar de cana. Brasil Açucareiro, p.21-27, abril 1974. 
LONDON, J. The ecology and taxonomic status of the lactobacilli. Annual Reviews Microbiology, v.30, p.279-301, 1976.

MAIORELLA, B.; BLANCH, H.W.; WILKE, C.R. By-Product inhibition effects on ethanolic fermentation by Saccharomyces cerevisiae. Biotechnology and Bioengineering, v.25, p.103-121, 1983.

MAKANJUOLA, D.B.; TYMON, A.; SPRINGHAM, D.G. Some effects of lactic acid bacteria on laboratory scale yeast fermentations. Enzyme and Microbial Technology, v.14, p.351-357, 1992.

NARENDRANATH, N.V.; HYNES， S.H.; THOMAS， K.C.; INGLEDEW，W.M. Effects of lactobacilli on yeast-catalyzed ethanol fermentations. Applied and Environmental Microbiology, v.63, n.11, p.4158-4163, Nov. 1997.

NELSON, H. A Photometric adaptation of the Somogyi Method. Journal of Biological Chemistry, v.153, p.375-380, 1944.

NODA, F.; HAYASHI, K.; MIZUNUMA, T. Antagonism between osmophilic lactic acid bacteria and yeasts in brine fermentation of soy sauce. Applied and Environmental Microbiology, v.40, n.3, p.452-457, Sept. 1980. 
NOVAES, F.V. Processos fermentativos. In: MUTTON, M.J.R. (ed.) Aguardente de cana : produção e qualidade. Jaboticabal: Funep, 1992. p.37-48.

OLIVA-NETO, P. de; YOKOYA, F. Influência do extrato de levedura na estabilidade da fermentação alcoólica contaminada por Lactobacillus fermentum. Ciência e Tecnologia de Alimentos, v.16, n.2, p.170-174, jul/set. 1996.

OLIVA-NETO, P. de; YOKOYA, F. Effects of nutritional factors on growth of Lactobacillus fermentum mixed with Saccharomyces cerevisiae in alcoholic fermentation. Revista de Microbiologia, v.28, p.25-31, 1997.

PARK, Y.K.; SATO, H.H. Fungal invertase as an aid for fermentation of cane molasses into ethanol. Applied and Environmental Microbiology, v.44, n.4, p.988-989, Oct. 1982.

PARROU, J.L.; FRANCOIS, J.A. Simplified procedure for a rapid and reliable assay of both glycogen and trealose in whole yeast cells. Analitical Biochemistry, v.248, n.1, p.186-188, 1997.

PRICE, R.J.; LEE, J.S. Inhibition of Pseudomonas species by hydrogen peroxide producing lactobacilli. Journal of Milk and Food Technology, v.33, p.13-18, 1970. 
PROCEEDINGS OF THE IV LONG ASHTON SYMPOSIUM, London, 1975. Lactic acid bacteria in beverages and foods. London: Academic Press, 1975. p.165-175.

SANTOS, M.T.; YOKOYA, F. Characteristics of yeast cell flocullation by Lactobacillus fermentum. Journal of Fermentation and Bioengineering, v.75, p.151-154, 1992.

SILVA, N. da; CANHOS, V.P. Caracterização da microbiota bacteriana contaminante do caldo de cana durante a etapa de resfriamento em torre no processo de produção de álcool. Coletânea do ITAL, v.20, n.1, p.60-72, jan/jun. 1990.

SMITH, S.; HILLIER, A.J.; LEES, G.J. The nature of the stimulation of the growth of Streptococcus lactis by yeast extract. Journal of Dairy Research, v.42, p.123-138, 1975.

STROPPA, C.T.; SERRA, G.; ANDRIETTA, M.G.S.; STECKELBERG, C.; ANDRIETTA, S.R. Consumo de açúcar por bactérias contaminantes da fermentação alcoólica associado ao uso de antibióticos. STAB, v.16, n.3, p.35-38, jan/fev., 1998.

TAKESHIGE, K.; OUCHI, K. Effects of yeast invertase on ethanol production in molasses. Journal of Fermentation and Bioengineering, v.79, n.5, p.513-515, 1995. 
TANI, Y.; SCHIMOIDE, M.; SUMINO, K.; FUKUI, S. Influence of culture condition on coagulation of Saccharomyces sake ocurring in media containing lactic acid. Journal of Fermentation Technology, v.41, p.445-450, 1963.

TREVELYAN, W.E.; HARRISON, J.S. Studies on yeast metabolism 5. The trealose content of baker's yeast during anaerobic fermentation. Biochemical Journal, v.62, p.177-183, 1956a.

TREVELYAN, W.E.; HARRISON, J.S. Studies on yeast metabolism 7. Yeast carbohydrate fraction. Separation from nucleic acid analysis and behaviour during anaerobic fermentation. Biochemical Journal, v.63, p.23-33, $1956 \mathrm{~b}$.

VILLELA, G.G.; BACILA, M.; TASTALDI, H. Técnicas e experimentos de Bioquímica. São Paulo: Guanabara Koogan, 1973. 552p.

VITOLO, M.; BORZANI, W. Measurement of invertase activity of cells of Saccharomyces cerevisiae. Analytical Biochemistry, v.130, p.469-470, 1983.

VITOLO, M.; CARVALHO, J.C.M.; DURANTI, M.A., BREDA, M. Invertase activity of intact yeast cells harvested from fed-batch ethanol fermentation of sugar cane blackstrap molasses. Biomass and Bioenergy, v.1, n.5, p.301-304, 1991. 
VITOLO, M.; DURANTI, M.A.; PELLEGRIM, M.B. Effect of $\mathrm{pH}$, aeration and sucrose feeding on the invertase activity of intact $S$. cerevisiae cells grown in sugarcane blackstrap molasses. Journal of Industrial Microbiology, v.15, p.75-79, 1995.

VITOLO, M.; VAIRO, M.L.R.; BORZANI, W. Invertase activity of intact cells of Saccharomyces cerevisiae growing on sugarcane molasses. I. Steady-state continuous culture tests. Biotechnology and Bioengineering, v.27, p.1229-1235, 1985.

VITOLO, M.; VAIRO, M.L.R.; BORZANI, W. Invertase activity of intact cells of Saccharomyces cerevisiae growing on sugarcane molasses. II. Unsteady-state continuous culture tests. Biotechnology and Bioengineering, v.30, p.9-14, 1987.

VITOLO, M.; YASSUDA, M.T. Effect of sucrose concentration on the invertase activity of intact yeast cells (S. cerevisiae). Biotechnology Letters, v.13, n.1, p.53$56,1991$.

WHEALS, A.E.; BASSO, L.C.; ALVES, D.M.G.; AMORIM, H.V. Fuel ethanol after 25 years. Trends in Biotechnology, v.17, n.12, p.482-487, 1999.

YOKOYA, F. Problemas com contaminantes na fermentação alcoólica. STAB, p.38-39, jul/ago., 1991. 
YOKOYA, F.; OLIVA-NETO, P. de Caracteristicas da floculação de leveduras por Lactobacillus fermentum. Revista de Microbiologia, v.22, n.1, p.12-16, 1991.

ZAGO, E.P.; AMORIM, H.V.; BASSO, L.C.; GUTIERREZ, L.E.; OLIVEIRA, A.J. Métodos analíticos para o controle da produção de álcool. Piracicaba: Fermentec/ESALQ-USP, 1989, 144p. 
APENDICES 


\begin{tabular}{|c|c|c|c|c|c|c|c|c|c|c|c|}
\hline Horas & Água & $\begin{array}{c}\text { AV- } \\
\text { PE }\end{array}$ & $\begin{array}{c}\text { AV- } \\
\text { BG }\end{array}$ & $\begin{array}{c}\text { AV- } \\
\text { FLE }\end{array}$ & $\begin{array}{c}\text { AV- } \\
\text { IZ }\end{array}$ & $\begin{array}{c}\text { AV- } \\
\text { CAT }\end{array}$ & $\begin{array}{c}\text { V- } \\
\text { PE }\end{array}$ & $\begin{array}{c}\text { V- } \\
\text { BG }\end{array}$ & $\begin{array}{c}\text { V- } \\
\text { FLE }\end{array}$ & $\begin{array}{c}\text { V- } \\
\text { IZ }\end{array}$ & $\begin{array}{c}\text { V- } \\
\text { CAT }\end{array}$ \\
\hline 0 & $\mathbf{0}$ & $\mathbf{0}$ & $\mathbf{0}$ & $\mathbf{0}$ & $\mathbf{0}$ & $\mathbf{0}$ & $\mathbf{0}$ & $\mathbf{0}$ & $\mathbf{0}$ & $\mathbf{0}$ & $\mathbf{0}$ \\
\hline 2 & $\mathbf{9 , 0}$ & $\mathbf{6 , 6}$ & $\mathbf{6 , 0}$ & $\mathbf{4 , 7}$ & $\mathbf{6 , 0}$ & $\mathbf{7 , 3}$ & $\mathbf{3 , 3}$ & $\mathbf{6 , 6}$ & $\mathbf{1 , 7}$ & $\mathbf{1 , 6}$ & $\mathbf{1 , 6}$ \\
\hline 4 & $\mathbf{2 9 , 4}$ & $\mathbf{1 2 , 6}$ & $\mathbf{1 2 , 7}$ & $\mathbf{1 2 , 0}$ & $\mathbf{1 6 , 0}$ & $\mathbf{1 7 , 3}$ & $\mathbf{5 , 0}$ & $\mathbf{1 0 , 0}$ & $\mathbf{3 , 4}$ & $\mathbf{6 , 6}$ & $\mathbf{8 , 3}$ \\
\hline 6 & $\mathbf{5 0 , 0}$ & $\mathbf{2 3 , 3}$ & $\mathbf{2 3 , 3}$ & $\mathbf{2 2 , 7}$ & $\mathbf{2 6 , 0}$ & $\mathbf{3 0 , 7}$ & $\mathbf{6 , 6}$ & $\mathbf{1 1 , 6}$ & $\mathbf{6 , 7}$ & $\mathbf{8 , 3}$ & $\mathbf{1 3 , 3}$ \\
\hline 8 & $\mathbf{6 4 , 4}$ & $\mathbf{4 4 , 6}$ & $\mathbf{4 3 , 3}$ & $\mathbf{4 2 , 0}$ & $\mathbf{4 4 , 6}$ & $\mathbf{5 0 , 0}$ & $\mathbf{2 5 , 0}$ & $\mathbf{2 5 , 0}$ & $\mathbf{2 3 , 4}$ & $\mathbf{2 1 , 6}$ & $\mathbf{3 1 , 6}$ \\
\hline 10 & $\mathbf{8 2 , 7}$ & $\mathbf{5 9 , 6}$ & $\mathbf{5 9 , 0}$ & $\mathbf{5 8 , 4}$ & $\mathbf{6 1 , 3}$ & $\mathbf{6 6 , 7}$ & $\mathbf{4 3 , 3}$ & $\mathbf{3 8 , 3}$ & $\mathbf{3 1 , 7}$ & $\mathbf{3 3 , 3}$ & $\mathbf{4 5 , 0}$ \\
\hline 12 & $\mathbf{9 8 , 4}$ & $\mathbf{8 4 , 6}$ & $\mathbf{7 2 , 3}$ & $\mathbf{7 1 , 7}$ & $\mathbf{7 9 , 6}$ & $\mathbf{8 2 , 7}$ & $\mathbf{5 3 , 3}$ & $\mathbf{4 5 , 0}$ & $\mathbf{4 8 , 4}$ & $\mathbf{5 0 , 0}$ & $\mathbf{6 1 , 6}$ \\
\hline 24 & $\mathbf{2 0 4 , 7}$ & $\mathbf{1 2 9 , 3}$ & $\mathbf{1 2 5 , 7}$ & $\mathbf{1 2 5 , 0}$ & $\mathbf{1 3 6 , 3}$ & $\mathbf{1 3 6 , 0}$ & $\mathbf{1 0 3 , 3}$ & $\mathbf{8 8 , 3}$ & $\mathbf{9 6 , 7}$ & $\mathbf{9 6 , 6}$ & $\mathbf{1 0 6 , 6}$ \\
\hline 26 & $\mathbf{2 0 4 , 0}$ & $\mathbf{1 2 9 , 3}$ & $\mathbf{1 2 4 , 0}$ & $\mathbf{1 2 3 , 4}$ & $\mathbf{1 3 3 , 0}$ & $\mathbf{1 3 1 , 0}$ & $\mathbf{9 6 , 6}$ & $\mathbf{7 8 , 3}$ & $\mathbf{8 6 , 7}$ & $\mathbf{9 3 , 3}$ & $\mathbf{1 0 0 , 0}$ \\
\hline 28 & $\mathbf{2 0 8 , 7}$ & $\mathbf{1 3 1 , 0}$ & $\mathbf{1 2 2 , 3}$ & $\mathbf{1 2 5 , 0}$ & $\mathbf{1 3 6 , 3}$ & $\mathbf{1 3 4 , 3}$ & $\mathbf{1 0 3 , 3}$ & $\mathbf{8 8 , 3}$ & $\mathbf{9 3 , 4}$ & $\mathbf{1 0 0 , 0}$ & $\mathbf{1 0 6 , 6}$ \\
\hline 30 & $\mathbf{2 1 2 , 7}$ & $\mathbf{1 3 1 , 0}$ & $\mathbf{1 2 0 , 7}$ & $\mathbf{1 2 3 , 4}$ & $\mathbf{1 3 1 , 3}$ & $\mathbf{1 3 1 , 0}$ & $\mathbf{1 0 0 , 0}$ & $\mathbf{7 8 , 3}$ & $\mathbf{8 6 , 7}$ & $\mathbf{9 0 , 0}$ & $\mathbf{1 1 2 , 3}$ \\
\hline
\end{tabular}

Quadro 1 - Curva de crescimento de lactobacilos em vinhos ajustados para $\mathrm{pH} 5,00 \mathrm{e}$ teor de álcool de aproximadamente 3,26\%.Variação da absorbância em relação ao tempo (média de 3 leituras) (primeiro experimento).

\begin{tabular}{|c|c|c|c|c|c|c|c|c|c|c|c|}
\hline Horas & Agua & $\begin{array}{c}\text { AV- } \\
\text { PE }\end{array}$ & $\begin{array}{c}\text { AV- } \\
\text { BG }\end{array}$ & $\begin{array}{c}\text { AV- } \\
\text { FLE }\end{array}$ & $\begin{array}{c}\text { AV- } \\
\text { IZ }\end{array}$ & $\begin{array}{c}\text { AV- } \\
\text { CAT }\end{array}$ & $\begin{array}{c}\text { V- } \\
\text { PE }\end{array}$ & $\begin{array}{c}\text { V- } \\
\text { BG }\end{array}$ & $\begin{array}{c}\text { V- } \\
\text { FLE }\end{array}$ & $\begin{array}{c}\text { V- } \\
\text { IZ }\end{array}$ & $\begin{array}{c}\text { V- } \\
\text { CAT }\end{array}$ \\
\hline 0 & $\mathbf{0}$ & $\mathbf{0}$ & $\mathbf{0}$ & $\mathbf{0}$ & $\mathbf{0}$ & $\mathbf{0}$ & $\mathbf{0}$ & $\mathbf{0}$ & $\mathbf{0}$ & $\mathbf{0}$ & $\mathbf{0}$ \\
\hline 2 & $\mathbf{0 , 6 9}$ & $\mathbf{0 , 5 0}$ & $\mathbf{0 , 4 6}$ & $\mathbf{0 , 3 6}$ & $\mathbf{0 , 4 6}$ & $\mathbf{0 , 5 6}$ & $\mathbf{0 , 2 5}$ & $\mathbf{0 , 5 6}$ & $\mathbf{0 , 1 3}$ & $\mathbf{0 , 1 2}$ & $\mathbf{0 , 1 2}$ \\
\hline 4 & $\mathbf{2 , 2 6}$ & $\mathbf{0 , 9 6}$ & $\mathbf{0 , 9 7}$ & $\mathbf{0 , 9 2}$ & $\mathbf{1 , 2 3}$ & $\mathbf{1 , 3 3}$ & $\mathbf{0 , 3 8}$ & $\mathbf{0 , 7 6}$ & $\mathbf{0 , 2 6}$ & $\mathbf{0 , 5 0}$ & $\mathbf{0 , 6 3}$ \\
\hline 6 & $\mathbf{3 , 8 4}$ & $\mathbf{1 , 7 9}$ & $\mathbf{1 , 7 9}$ & $\mathbf{1 , 7 4}$ & $\mathbf{2 , 0 0}$ & $\mathbf{2 , 3 6}$ & $\mathbf{0 , 5 0}$ & $\mathbf{0 , 8 9}$ & $\mathbf{0 , 5 1}$ & $\mathbf{0 , 6 3}$ & $\mathbf{1 , 0 2}$ \\
\hline $\mathbf{8}$ & $\mathbf{4 , 9 5}$ & $\mathbf{3 , 4 3}$ & $\mathbf{3 , 3 3}$ & $\mathbf{3 , 2 3}$ & $\mathbf{3 , 4 3}$ & $\mathbf{3 , 8 4}$ & $\mathbf{1 , 9 2}$ & $\mathbf{1 , 9 2}$ & $\mathbf{1 , 8 0}$ & $\mathbf{1 , 6 6}$ & $\mathbf{2 , 4 3}$ \\
\hline 10 & $\mathbf{6 , 3 6}$ & $\mathbf{4 , 5 8}$ & $\mathbf{4 , 5 4}$ & $\mathbf{4 , 4 9}$ & $\mathbf{4 , 7 1}$ & $\mathbf{5 , 1 3}$ & $\mathbf{3 , 3 3}$ & $\mathbf{2 , 9 4}$ & $\mathbf{2 , 4 4}$ & $\mathbf{2 , 5 6}$ & $\mathbf{3 , 4 6}$ \\
\hline 12 & $\mathbf{7 , 5 7}$ & $\mathbf{6 , 5 1}$ & $\mathbf{5 , 5 6}$ & $\mathbf{5 , 5 1}$ & $\mathbf{6 , 1 2}$ & $\mathbf{6 , 3 6}$ & $\mathbf{4 , 1 0}$ & $\mathbf{3 , 4 6}$ & $\mathbf{3 , 7 2}$ & $\mathbf{3 , 8 4}$ & $\mathbf{4 , 7 4}$ \\
\hline 24 & $\mathbf{1 5 , 7 5}$ & $\mathbf{9 , 9 5}$ & $\mathbf{9 , 6 7}$ & $\mathbf{9 , 6 2}$ & $\mathbf{1 0 , 4 9}$ & $\mathbf{1 0 , 4 6}$ & $\mathbf{7 , 9 5}$ & $\mathbf{6 , 7 9}$ & $\mathbf{7 , 4 4}$ & $\mathbf{7 , 4 3}$ & $\mathbf{8 , 2 0}$ \\
\hline 26 & $\mathbf{1 5 , 7 0}$ & $\mathbf{9 , 9 5}$ & $\mathbf{9 , 5 4}$ & $\mathbf{9 , 4 9}$ & $\mathbf{1 0 , 2 3}$ & $\mathbf{1 0 , 0 8}$ & $\mathbf{7 , 4 3}$ & $\mathbf{6 , 0 2}$ & $\mathbf{6 , 6 7}$ & $\mathbf{7 , 1 8}$ & $\mathbf{7 , 6 9}$ \\
\hline 28 & $\mathbf{1 6 , 0 6}$ & $\mathbf{1 0 , 0 8}$ & $\mathbf{9 , 4 1}$ & $\mathbf{9 , 6 2}$ & $\mathbf{1 0 , 4 9}$ & $\mathbf{1 0 , 3 3}$ & $\mathbf{7 , 9 5}$ & $\mathbf{6 , 7 9}$ & $\mathbf{7 , 1 9}$ & $\mathbf{7 , 6 9}$ & $\mathbf{8 , 2 0}$ \\
\hline 30 & $\mathbf{1 6 , 3 7}$ & $\mathbf{1 0 , 0 8}$ & $\mathbf{9 , 2 9}$ & $\mathbf{9 , 4 9}$ & $\mathbf{1 0 , 1 0}$ & $\mathbf{1 0 , 0 8}$ & $\mathbf{7 , 6 9}$ & $\mathbf{6 , 0 2}$ & $\mathbf{6 , 6 7}$ & $\mathbf{6 , 9 2}$ & $\mathbf{8 , 6 4}$ \\
\hline
\end{tabular}

Quadro 2 - Curva de crescimento de lactobacilos em vinhos ajustados para $\mathrm{pH} 5,00 \mathrm{e}$ teor de álcool de aproximadamente 3,26\%.Variação da UFC ( $\left(1^{8}\right) / \mathrm{mL}$ em relação ao tempo (média de 3 leituras) (primeiro experimento). Essa tabela foi construida à partir dos dados de variação da absorbância pelo tempo (tabela 1). 


\begin{tabular}{|c|c|c|c|c|c|c|c|c|c|c|c|}
\hline Horas & Água & $\begin{array}{c}\text { AV- } \\
\text { PE }\end{array}$ & $\begin{array}{c}\text { AV- } \\
\text { BG }\end{array}$ & $\begin{array}{c}\text { AV- } \\
\text { FLE }\end{array}$ & $\begin{array}{c}\text { AV- } \\
\text { IZ }\end{array}$ & $\begin{array}{c}\text { AV- } \\
\text { CAT }\end{array}$ & $\begin{array}{c}\text { V- } \\
\text { PE }\end{array}$ & $\begin{array}{c}\text { V- } \\
\text { BG }\end{array}$ & $\begin{array}{c}\text { V- } \\
\text { FLE }\end{array}$ & $\begin{array}{c}\text { V- } \\
\text { IZ }\end{array}$ & $\begin{array}{c}\text { V- } \\
\text { CAT }\end{array}$ \\
\hline 0 & $\mathbf{0}$ & $\mathbf{0}$ & $\mathbf{0}$ & $\mathbf{0}$ & $\mathbf{0}$ & $\mathbf{0}$ & $\mathbf{0}$ & $\mathbf{0}$ & $\mathbf{0}$ & $\mathbf{0}$ & $\mathbf{0}$ \\
\hline 2 & $\mathbf{5 , 7}$ & $\mathbf{4 , 0}$ & $\mathbf{4 , 0}$ & $\mathbf{4 , 3}$ & $\mathbf{6 , 0}$ & $\mathbf{4 , 3}$ & $\mathbf{1 , 7}$ & $\mathbf{1 , 6}$ & $\mathbf{6 , 7}$ & $\mathbf{8 , 3}$ & $\mathbf{3 , 4}$ \\
\hline 4 & $\mathbf{2 0 , 0}$ & $\mathbf{2 0 , 0}$ & $\mathbf{2 0 , 0}$ & $\mathbf{2 6 , 3}$ & $\mathbf{2 4 , 6}$ & $\mathbf{2 3 , 0}$ & $\mathbf{1 6 , 7}$ & $\mathbf{1 6 , 6}$ & $\mathbf{2 6 , 7}$ & $\mathbf{2 3 , 3}$ & $\mathbf{2 0 , 0}$ \\
\hline 6 & $\mathbf{3 7 , 7}$ & $\mathbf{2 6 , 7}$ & $\mathbf{2 6 , 6}$ & $\mathbf{3 4 , 3}$ & $\mathbf{3 3 , 3}$ & $\mathbf{3 1 , 6}$ & $\mathbf{2 5 , 0}$ & $\mathbf{3 0 , 0}$ & $\mathbf{3 5 , 0}$ & $\mathbf{3 5 , 0}$ & $\mathbf{3 0 , 0}$ \\
\hline 8 & $\mathbf{5 7 , 4}$ & $\mathbf{3 2 , 7}$ & $\mathbf{3 3 , 3}$ & $\mathbf{4 1 , 7}$ & $\mathbf{3 8 , 0}$ & $\mathbf{3 7 , 6}$ & $\mathbf{2 5 , 0}$ & $\mathbf{3 0 , 0}$ & $\mathbf{3 0 , 0}$ & $\mathbf{3 1 , 7}$ & $\mathbf{3 0 , 0}$ \\
\hline 10 & $\mathbf{7 1 , 7}$ & $\mathbf{3 7 , 4}$ & $\mathbf{3 8 , 0}$ & $\mathbf{4 7 , 7}$ & $\mathbf{4 5 , 3}$ & $\mathbf{4 3 , 6}$ & $\mathbf{2 5 , 0}$ & $\mathbf{2 8 , 3}$ & $\mathbf{2 6 , 7}$ & $\mathbf{3 0 , 0}$ & $\mathbf{2 6 , 7}$ \\
\hline 12 & $\mathbf{9 3 , 7}$ & $\mathbf{5 1 , 4}$ & $\mathbf{5 0 , 0}$ & $\mathbf{5 9 , 7}$ & $\mathbf{5 7 , 3}$ & $\mathbf{5 4 , 3}$ & $\mathbf{2 8 , 4}$ & $\mathbf{3 0 , 0}$ & $\mathbf{3 1 , 7}$ & $\mathbf{3 3 , 3}$ & $\mathbf{3 0 , 0}$ \\
\hline 24 & $\mathbf{1 9 0 , 0}$ & $\mathbf{1 1 0 , 4}$ & $\mathbf{1 0 4 , 6}$ & $\mathbf{1 1 6 , 3}$ & $\mathbf{1 1 2 , 6}$ & $\mathbf{1 0 8 , 3}$ & $\mathbf{6 8 , 4}$ & $\mathbf{6 6 , 6}$ & $\mathbf{7 0 , 0}$ & $\mathbf{7 1 , 7}$ & $\mathbf{6 6 , 7}$ \\
\hline 26 & $\mathbf{2 0 4 , 0}$ & $\mathbf{1 2 2 , 0}$ & $\mathbf{1 1 6 , 3}$ & $\mathbf{1 2 8 , 0}$ & $\mathbf{1 2 4 , 3}$ & $\mathbf{1 2 0 , 0}$ & $\mathbf{7 5 , 0}$ & $\mathbf{7 5 , 0}$ & $\mathbf{7 6 , 7}$ & $\mathbf{8 0 , 0}$ & $\mathbf{7 3 , 4}$ \\
\hline 28 & $\mathbf{2 1 1 , 4}$ & $\mathbf{1 2 7 , 0}$ & $\mathbf{1 2 3 , 0}$ & $\mathbf{1 3 3 , 0}$ & $\mathbf{1 2 9 , 3}$ & $\mathbf{1 2 5 , 0}$ & $\mathbf{8 0 , 0}$ & $\mathbf{7 6 , 6}$ & $\mathbf{7 8 , 3}$ & $\mathbf{8 1 , 7}$ & $\mathbf{7 3 , 4}$ \\
\hline 30 & $\mathbf{2 1 6 , 7}$ & $\mathbf{1 2 5 , 4}$ & $\mathbf{1 2 1 , 3}$ & $\mathbf{1 3 1 , 3}$ & $\mathbf{1 2 9 , 3}$ & $\mathbf{1 2 3 , 3}$ & $\mathbf{7 5 , 0}$ & $\mathbf{7 3 , 3}$ & $\mathbf{7 6 , 7}$ & $\mathbf{8 0 , 0}$ & $\mathbf{7 0 , 0}$ \\
\hline 32 & $\mathbf{2 2 0 , 7}$ & $\mathbf{1 2 8 , 7}$ & $\mathbf{1 2 3 , 0}$ & $\mathbf{1 3 3 , 0}$ & $\mathbf{1 3 1 , 0}$ & $\mathbf{1 2 5 , 0}$ & $\mathbf{7 6 , 7}$ & $\mathbf{7 5 , 0}$ & $\mathbf{7 6 , 7}$ & $\mathbf{8 1 , 7}$ & $\mathbf{7 3 , 4}$ \\
\hline
\end{tabular}

Quadro 3 - Curva de crescimento de lactobacilos em vinhos ajustados para $\mathrm{pH} 5,00 \mathrm{e}$ teor de álcool de aproximadamente 3,68\%.Variação da absorbância em relação ao tempo (média de 3 leituras) (segundo experimento).

\begin{tabular}{|c|c|c|c|c|c|c|c|c|c|c|c|}
\hline Horas & Água & $\begin{array}{c}\text { AV- } \\
\text { PE }\end{array}$ & $\begin{array}{c}\text { AV- } \\
\text { BG }\end{array}$ & $\begin{array}{c}\text { AV- } \\
\text { FLE }\end{array}$ & $\begin{array}{c}\text { AV- } \\
\text { IZ }\end{array}$ & $\begin{array}{c}\text { AV- } \\
\text { CAT }\end{array}$ & $\begin{array}{c}\text { V- } \\
\text { PE }\end{array}$ & $\begin{array}{c}\text { V- } \\
\text { BG }\end{array}$ & $\begin{array}{c}\text { V- } \\
\text { FLE }\end{array}$ & $\begin{array}{c}\text { V- } \\
\text { IZ }\end{array}$ & $\begin{array}{c}\text { V- } \\
\text { CAT }\end{array}$ \\
\hline 0 & $\mathbf{0}$ & $\mathbf{0}$ & $\mathbf{0}$ & $\mathbf{0}$ & $\mathbf{0}$ & $\mathbf{0}$ & $\mathbf{0}$ & $\mathbf{0}$ & $\mathbf{0}$ & $\mathbf{0}$ & $\mathbf{0}$ \\
\hline 2 & $\mathbf{0 , 4 3}$ & $\mathbf{0 , 3 0}$ & $\mathbf{0 , 3 0}$ & $\mathbf{0 , 3 3}$ & $\mathbf{0 , 4 6}$ & $\mathbf{0 , 3 3}$ & $\mathbf{0 , 1 3}$ & $\mathbf{0 , 1 2}$ & $\mathbf{0 , 5 1}$ & $\mathbf{0 , 6 3}$ & $\mathbf{0 , 2 6}$ \\
\hline 4 & $\mathbf{1 , 5 3}$ & $\mathbf{1 , 5 3}$ & $\mathbf{1 , 5 3}$ & $\mathbf{2 , 0 2}$ & $\mathbf{1 , 8 9}$ & $\mathbf{1 , 7 7}$ & $\mathbf{1 , 2 8}$ & $\mathbf{1 , 2 7}$ & $\mathbf{2 , 0 5}$ & $\mathbf{1 , 7 9}$ & $\mathbf{1 , 5 3}$ \\
\hline 6 & $\mathbf{2 , 9 0}$ & $\mathbf{2 , 0 5}$ & $\mathbf{2 , 0 4}$ & $\mathbf{2 , 6 4}$ & $\mathbf{2 , 5 6}$ & $\mathbf{2 , 4 3}$ & $\mathbf{1 , 9 2}$ & $\mathbf{2 , 3 0}$ & $\mathbf{2 , 6 9}$ & $\mathbf{2 , 6 9}$ & $\mathbf{2 , 3 0}$ \\
\hline $\mathbf{8}$ & $\mathbf{4 , 4 1}$ & $\mathbf{2 , 5 1}$ & $\mathbf{2 , 5 6}$ & $\mathbf{3 , 2 1}$ & $\mathbf{2 , 9 2}$ & $\mathbf{2 , 8 9}$ & $\mathbf{1 , 9 2}$ & $\mathbf{2 , 3 0}$ & $\mathbf{2 , 3 0}$ & $\mathbf{2 , 4 4}$ & $\mathbf{2 , 3 0}$ \\
\hline 10 & $\mathbf{5 , 5 1}$ & $\mathbf{2 , 8 7}$ & $\mathbf{2 , 9 2}$ & $\mathbf{3 , 6 7}$ & $\mathbf{3 , 4 8}$ & $\mathbf{3 , 3 5}$ & $\mathbf{1 , 9 2}$ & $\mathbf{2 , 1 7}$ & $\mathbf{2 , 0 5}$ & $\mathbf{2 , 3 0}$ & $\mathbf{2 , 0 5}$ \\
\hline 12 & $\mathbf{7 , 2 1}$ & $\mathbf{3 , 9 5}$ & $\mathbf{3 , 8 4}$ & $\mathbf{4 , 5 9}$ & $\mathbf{4 , 4 1}$ & $\mathbf{3 , 7 4}$ & $\mathbf{2 , 1 8}$ & $\mathbf{2 , 3 0}$ & $\mathbf{2 , 4 4}$ & $\mathbf{2 , 5 6}$ & $\mathbf{2 , 3 0}$ \\
\hline 24 & $\mathbf{1 4 , 6 2}$ & $\mathbf{8 , 4 9}$ & $\mathbf{8 , 0 5}$ & $\mathbf{8 , 9 5}$ & $\mathbf{8 , 6 6}$ & $\mathbf{8 , 3 3}$ & $\mathbf{5 , 2 6}$ & $\mathbf{5 , 1 2}$ & $\mathbf{5 , 3 8}$ & $\mathbf{5 , 5 1}$ & $\mathbf{5 , 1 3}$ \\
\hline 26 & $\mathbf{1 5 , 7 0}$ & $\mathbf{9 , 3 9}$ & $\mathbf{8 , 9 5}$ & $\mathbf{9 , 8 5}$ & $\mathbf{9 , 5 6}$ & $\mathbf{9 , 2 3}$ & $\mathbf{5 , 7 7}$ & $\mathbf{5 , 7 7}$ & $\mathbf{5 , 9 0}$ & $\mathbf{6 , 1 5}$ & $\mathbf{5 , 6 5}$ \\
\hline 28 & $\mathbf{1 6 , 2 7}$ & $\mathbf{9 , 7 7}$ & $\mathbf{9 , 4 6}$ & $\mathbf{1 0 , 2 3}$ & $\mathbf{9 , 9 5}$ & $\mathbf{9 , 6 2}$ & $\mathbf{6 , 1 5}$ & $\mathbf{5 , 8 9}$ & $\mathbf{6 , 0 2}$ & $\mathbf{6 , 2 8}$ & $\mathbf{5 , 6 5}$ \\
\hline 30 & $\mathbf{1 6 , 6 8}$ & $\mathbf{9 , 6 5}$ & $\mathbf{9 , 3 3}$ & $\mathbf{1 0 , 1 0}$ & $\mathbf{9 , 9 5}$ & $\mathbf{9 , 4 9}$ & $\mathbf{5 , 7 7}$ & $\mathbf{5 , 6 4}$ & $\mathbf{5 , 9 0}$ & $\mathbf{6 , 1 5}$ & $\mathbf{5 , 3 8}$ \\
\hline 32 & $\mathbf{1 6 , 9 8}$ & $\mathbf{9 , 9 0}$ & $\mathbf{9 , 4 6}$ & $\mathbf{1 0 , 2 3}$ & $\mathbf{1 0 , 0 8}$ & $\mathbf{9 , 6 2}$ & $\mathbf{5 , 9 0}$ & $\mathbf{5 , 7 7}$ & $\mathbf{5 , 9 0}$ & $\mathbf{6 , 2 8}$ & $\mathbf{5 , 6 5}$ \\
\hline
\end{tabular}

Quadro 4 - Curva de crescimento de lactobacilos em vinhos ajustados para $\mathrm{pH} 5,00 \mathrm{e}$ teor de álcool de aproximadamente 3,68\%.Variação da UFC (x $\left.10^{8}\right) / \mathrm{mL}$ em relação ao tempo (média de 3 leituras) (segundo experimento). Essa tabela foi construída à partir dos dados de variação da absorbância pelo tempo (tabela 3). 


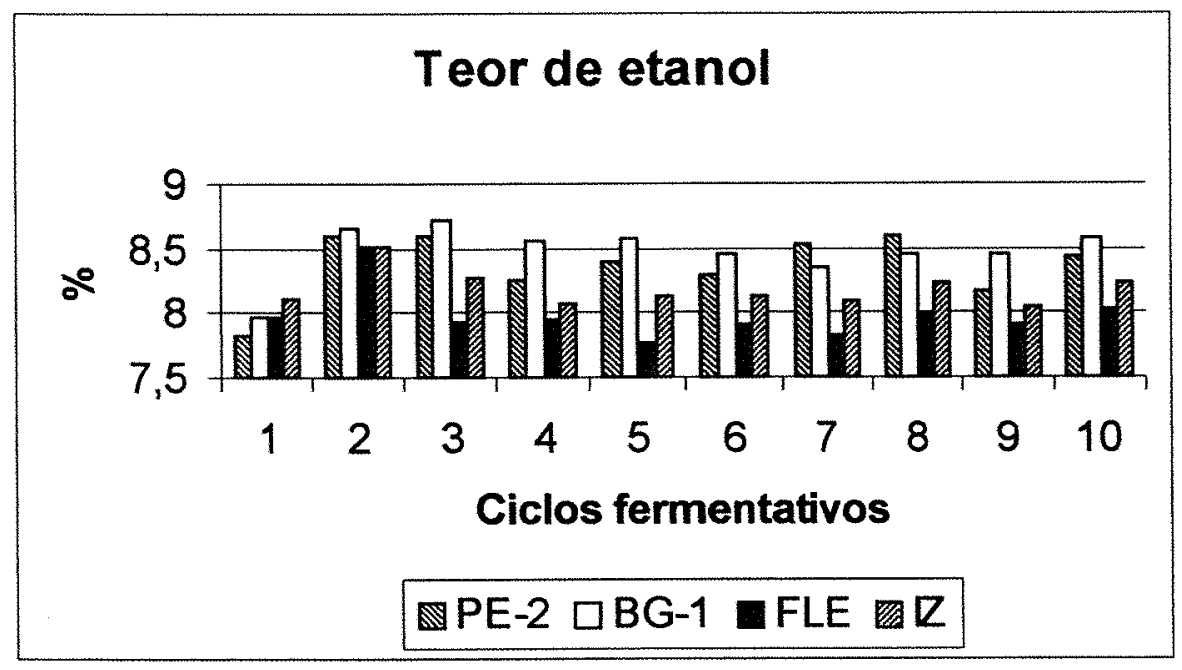

Figura 1 - Efeito de diferentes leveduras em co-cultura com lactobacilos ao longo de 10 ciclos fermentativos sobre o parâmetro teor de etanol.

Teste de Tukey para médias de tratamento e ciclo.

\begin{tabular}{cccc}
\hline Tratamento & Média & $5 \%$ & $1 \%$ \\
\hline BG-1 & 8,475 & a & A \\
PE-2 & 8,365 & a & A \\
IZ & 8,175 & ab & A \\
FLE & 7,978 & b & A \\
\hline
\end{tabular}

Médias seguidas por letras distintas diferem entre si ao nivel de significância indicado.

C.V. $=0,777 \%$

D.M.S. $5 \%=0,35113$

D.M.S. $1 \%=0,50377$

\begin{tabular}{cccc}
\hline Ciclo & Média & $5 \%$ & $1 \%$ \\
\hline 2 & 8,565 & a & A \\
3 & 8,376 & ab & AB \\
8 & 8,315 & bc & BC \\
10 & 8,309 & bc & BC \\
5 & 8,211 & bc & BC \\
4 & 8,210 & bc & BC \\
7 & 8,196 & bc & BC \\
6 & 8,191 & bc & BC \\
9 & 8,144 & cd & CD \\
1 & 7,966 & d & D \\
\hline
\end{tabular}

Médias seguidas por letras distintas diferem entre si ao nível de significância indicado.

C.V. $=1,746 \%$

D.M.S. $5 \%=0,19224$

D.M.S. $1 \%=0,22476$ 


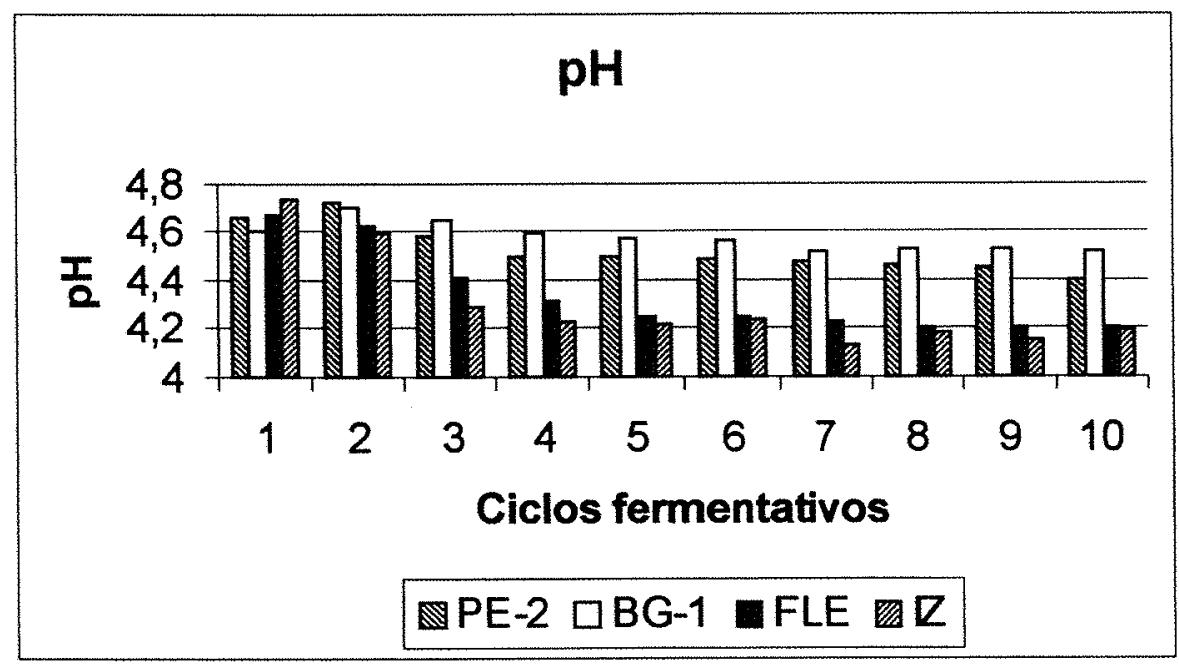

Figura 2 - Efeito de diferentes leveduras em co-cultura com lactobacilos ao longo de 10 ciclos fermentativos sobre o parâmetro teor de $\mathrm{pH}$.

Teste de Tukey para médias de tratamento e ciclo.

\begin{tabular}{cccc}
\hline Tratamento & Média & $5 \%$ & $1 \%$ \\
\hline BG-1 & 4,578 & a & A \\
PE-2 & 4,524 & a & AB \\
FLE & 4,338 & b & AB \\
IZ & 4,295 & b & B \\
\hline
\end{tabular}

Médias seguidas por letras distintas diferem entre si ao nivel de significância indicado.

C.V. $=0,738 \%$

D.M.S. $5 \%=0,17927$

D.M.S. $1 \%=0,25720$

\begin{tabular}{cccc}
\hline Ciclo & Média & $5 \%$ & $1 \%$ \\
\hline 1 & 4,668 & a & A \\
2 & 4,662 & a & A \\
3 & 4,483 & b & B \\
4 & 4,409 & c & C \\
6 & 4,385 & cd & CD \\
5 & 4,384 & cd & CDE \\
8 & 4,347 & de & DE \\
7 & 4,338 & de & DE \\
9 & 4,334 & e & DE \\
10 & 4,327 & e & E \\
\hline
\end{tabular}

Médias seguidas por letras distintas diferem entre si ao nivel de significância indicado.

C.V. $=0,828 \%$

D.M.S. $5 \%=0,04901$

D.M.S. $1 \%=0,05730$ 


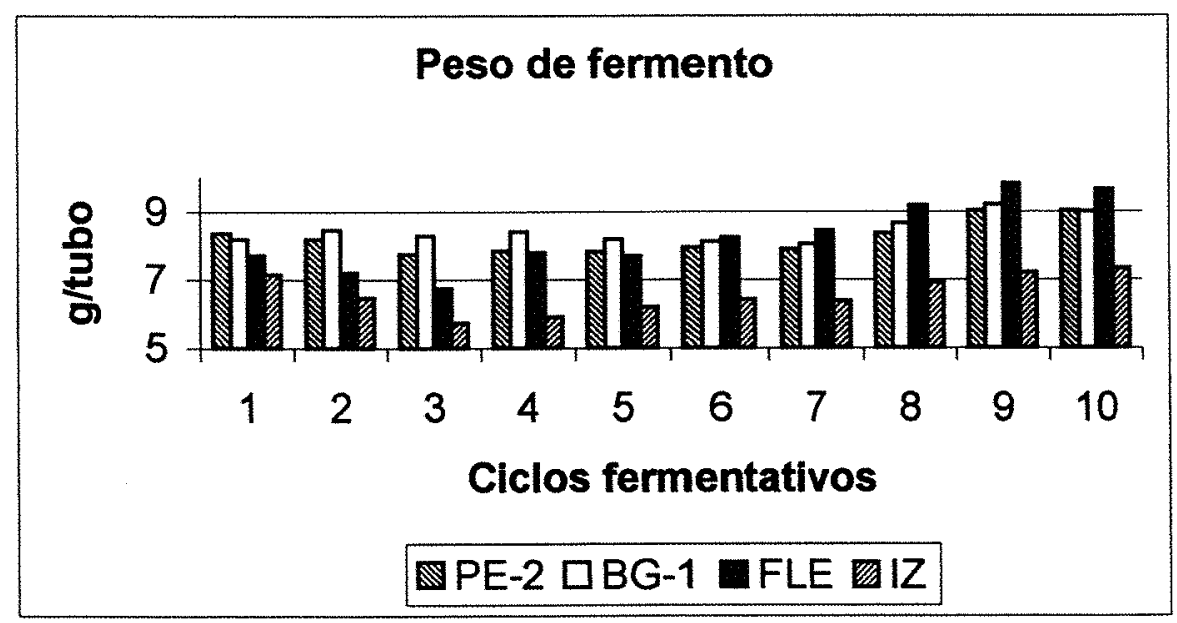

Figura 3 - Efeito de diferentes leveduras em co-cultura com lactobacilos ao longo de 10 ciclos fermentativos sobre o parâmetro peso de fermento.

Teste de Tukey para médias de tratamento e ciclo.

\begin{tabular}{cccc}
\hline Tratamento & Média & $5 \%$ & $1 \%$ \\
\hline BG-1 & 8,448 & a & A \\
PE-2 & 8,220 & ab & A \\
FLE & 8,200 & ab & A \\
IZ & 6,569 & b & A \\
\hline
\end{tabular}

Médias seguidas por letras distintas diferem entre si ao nível de significância indicado.

C.V. $=4,300 \%$

D.M.S. $5 \%=1,85164$

D.M.S. $1 \%=2,65653$

\begin{tabular}{cccc}
\hline Ciclo & Média & $5 \%$ & $1 \%$ \\
\hline 9 & 8,803 & a & A \\
10 & 8,747 & a & A \\
8 & 8,272 & b & B \\
1 & 7,858 & c & BC \\
7 & 7,676 & cd & CD \\
6 & 7,672 & cd & CD \\
2 & 7,583 & cd & CDE \\
5 & 7,475 & cde & CDE \\
4 & 7,383 & de & DE \\
3 & 7,121 & e & E \\
\hline
\end{tabular}

Médias seguidas por letras distintas diferem entre si ao nivel de significância indicado.

C.V. $=3,798 \%$

D.M.S. $5 \%=0,39837$

D.M.S. $1 \%=0,46576$ 


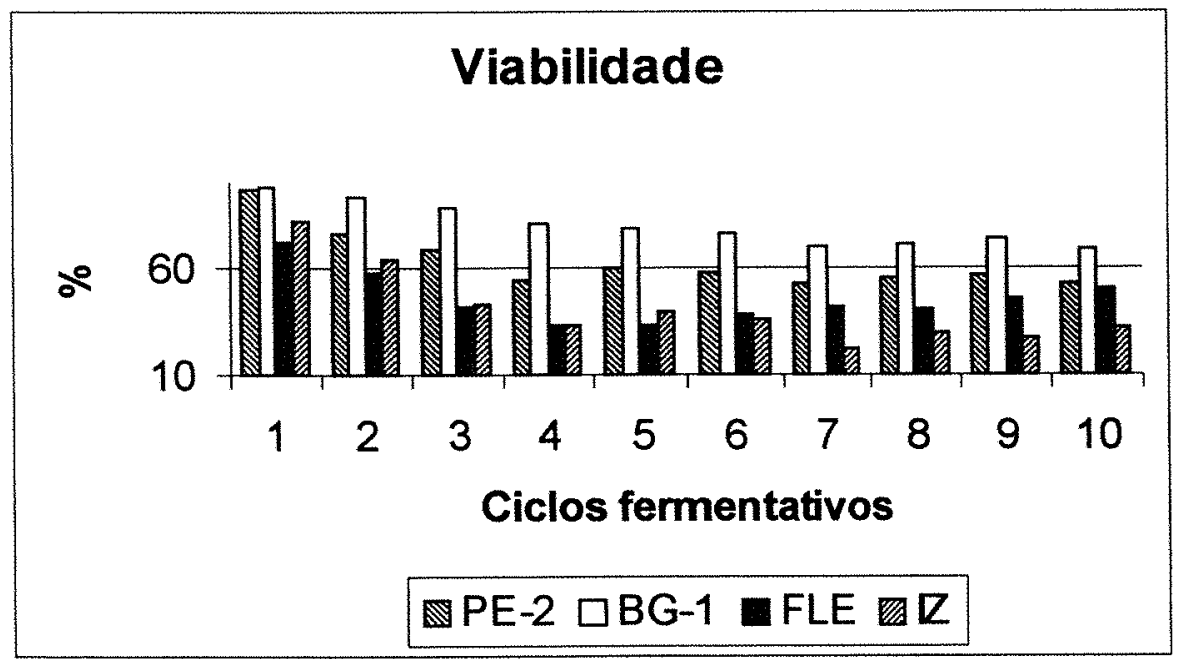

Figura 4 - Efeito de diferentes leveduras em co-cultura com lactobacilos ao longo de 10 ciclos fermentativos sobre o parâmetro viabilidade da levedura.

Teste de Tukey para médias de tratamento e ciclo.

\begin{tabular}{cccc}
\hline Tratamento & Média & $5 \%$ & $1 \%$ \\
\hline BG-1 & 79,13 & a & A \\
PE-2 & 62,63 & ab & A \\
FLE & 45,32 & ab & A \\
IZ & 41,08 & b & A \\
\hline
\end{tabular}

Médias seguidas por letras distintas diferem entre si ao nivel de significância indicado.

C.V. $=12,116 \%$

D.M.S. $5 \%=37,86383$

D.M.S. $1 \%=54,32300$

\begin{tabular}{cccc}
\hline Ciclo & Média & $5 \%$ & $1 \%$ \\
\hline 1 & 86,19 & a & A \\
2 & 72,16 & b & B \\
3 & 60,21 & c & C \\
5 & 52,47 & cd & CD \\
10 & 51,85 & d & CD \\
6 & 51,55 & d & CD \\
4 & 50,41 & d & D \\
9 & 50,35 & d & D \\
8 & 48,81 & d & D \\
7 & 46,38 & d & D \\
\hline
\end{tabular}

Médias seguidas por letras distintas diferem entre si ao nivel de significância indicado.

C.V. $=10,419 \%$

D.M.S. $5 \%=7,93195$

D.M.S. $1 \%=9,27367$ 


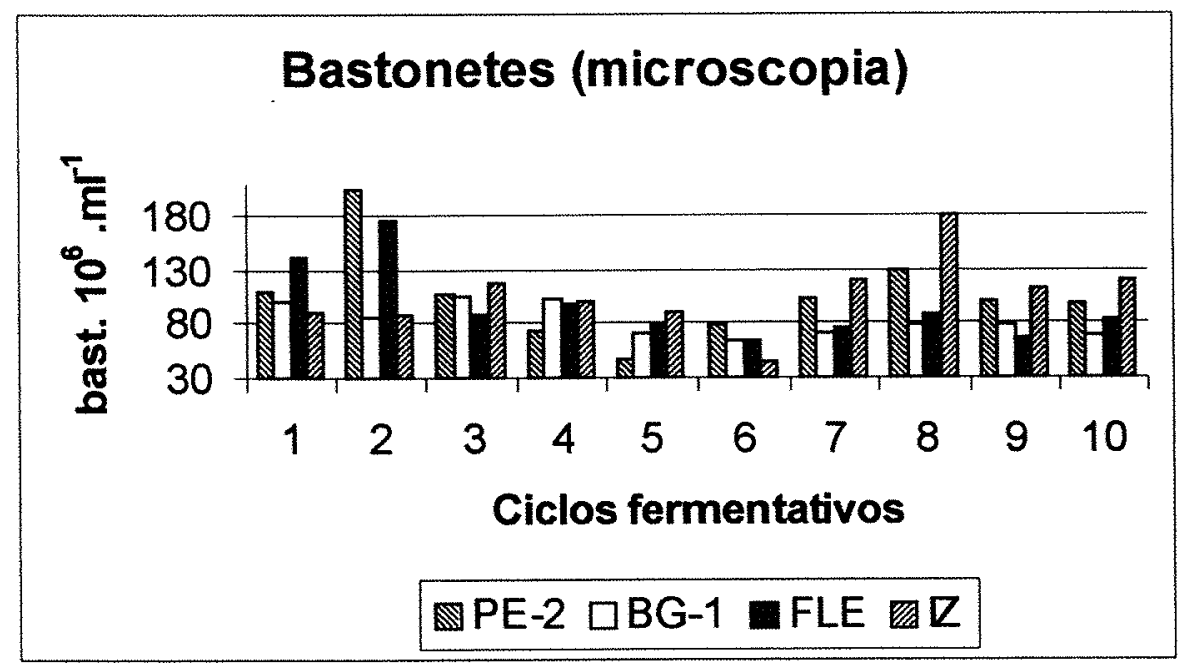

Figura 5 - Efeito de diferentes leveduras em co-cultura com lactobacilos ao longo de 10 ciclos fermentativos sobre o parâmetro número de bastonetes (microscopia).

Teste de Tukey para médias de tratamento e ciclo.

\begin{tabular}{cccc}
\hline Tratamento & Média & $5 \%$ & $1 \%$ \\
\hline IZ & 105,825 & a & A \\
PE-2 & 105,225 & a & A \\
FLE & 96,393 & a & A \\
BG-1 & 82,913 & a & A \\
\hline
\end{tabular}

Médias seguidas por letras distintas diferem entre si ao nível de significância indicado.

C.V. $=9,221 \%$

D.M.S. $5 \%=49,2992$

D.M.S. $1 \%=70,73030$

\begin{tabular}{cccc}
\hline Ciclo & Média & $5 \%$ & $1 \%$ \\
\hline 2 & 136,71 & $\mathrm{a}$ & $\mathrm{A}$ \\
8 & 119,38 & $\mathrm{ab}$ & $\mathrm{AB}$ \\
1 & 110,38 & $\mathrm{abc}$ & $\mathrm{ABC}$ \\
3 & 104,97 & abc & $\mathrm{ABC}$ \\
4 & 94,20 & $\mathrm{bcd}$ & $\mathrm{ABC}$ \\
7 & 92,75 & $\mathrm{bcd}$ & $\mathrm{ABC}$ \\
10 & 92,46 & bcd & $\mathrm{ABC}$ \\
9 & 89,77 & bcd & $\mathrm{ABC}$ \\
5 & 72,35 & cd & $\mathrm{BC}$ \\
6 & 62,86 & $\mathrm{~d}$ & $\mathrm{C}$ \\
\hline
\end{tabular}

Médias seguidas por letras distintas diferem entre si ao nivel de significância indicado.

C.V. $=32,279 \%$

D.M.S. $5 \%=42,03918$

D.M.S. $1 \%=49,15029$ 


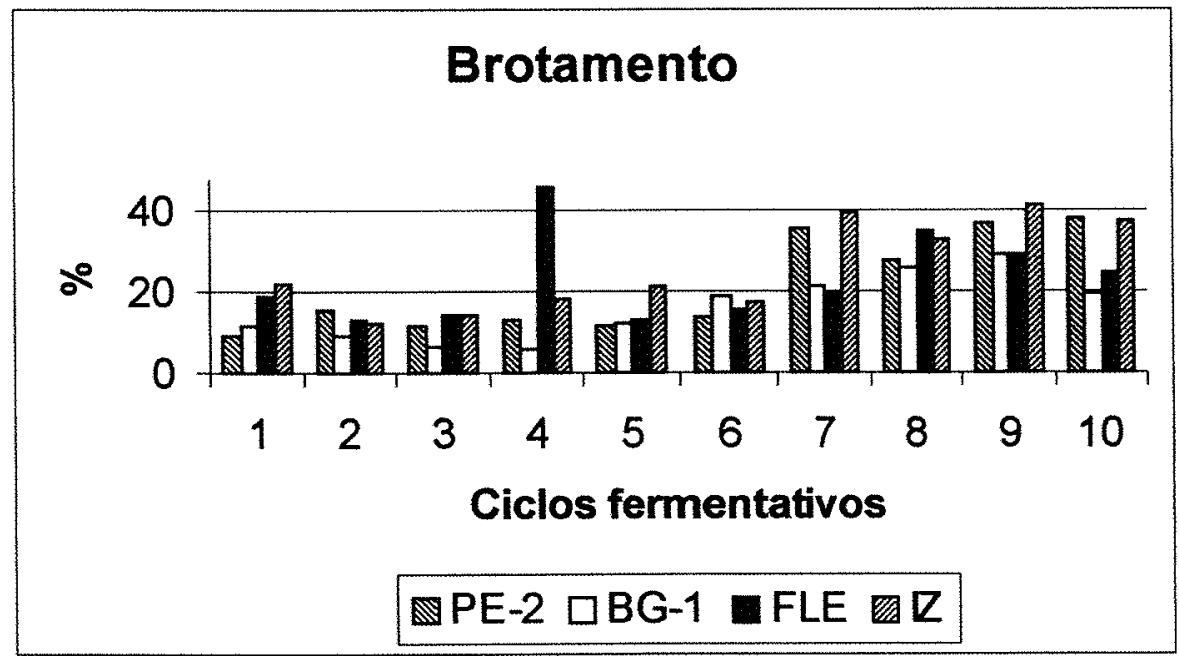

Figura 6 - Efeito de diferentes leveduras em co-cultura com lactobacilos ao longo de 10 ciclos fermentativos sobre o parâmetro brotamento da levedura.

Teste de Tukey para médias de tratamento e ciclo.

\begin{tabular}{cccc}
\hline Tratamento & Média & $5 \%$ & $1 \%$ \\
\hline IZ & 25,73 & a & A \\
FLE & 23,17 & a & A \\
PE-2 & 21,44 & a & A \\
BG-1 & 16,02 & a & A \\
\hline
\end{tabular}

Médias seguidas por letras distintas diferem entre si ao nível de significância indicado.

C.V. $=15,620 \%$

D.M.S. $5 \%=18,47825$

D.M.S. $1 \%=26,51064$

\begin{tabular}{cccc}
\hline Ciclo & Média & $5 \%$ & $1 \%$ \\
\hline 9 & 34,20 & $\mathrm{a}$ & $\mathrm{A}$ \\
8 & 30,51 & $\mathrm{a}$ & $\mathrm{AB}$ \\
10 & 29,93 & $\mathrm{a}$ & $\mathrm{AB}$ \\
7 & 29,79 & $\mathrm{a}$ & $\mathrm{AB}$ \\
4 & 20,57 & $\mathrm{~b}$ & $\mathrm{BC}$ \\
6 & 16,28 & $\mathrm{~b}$ & $\mathrm{C}$ \\
1 & 15,61 & $\mathrm{~b}$ & $\mathrm{C}$ \\
5 & 14,76 & $\mathrm{~b}$ & $\mathrm{C}$ \\
2 & 12,58 & $\mathrm{~b}$ & $\mathrm{C}$ \\
3 & 11,65 & $\mathrm{~b}$ & $\mathrm{C}$ \\
\hline
\end{tabular}

Médias seguidas por letras distintas diferem entre si ao nivel de significância indicado.

C.V. $=30,990 \%$

D.M.S. $5 \%=8,93035$

D.M.S. $1 \%=10,44096$ 


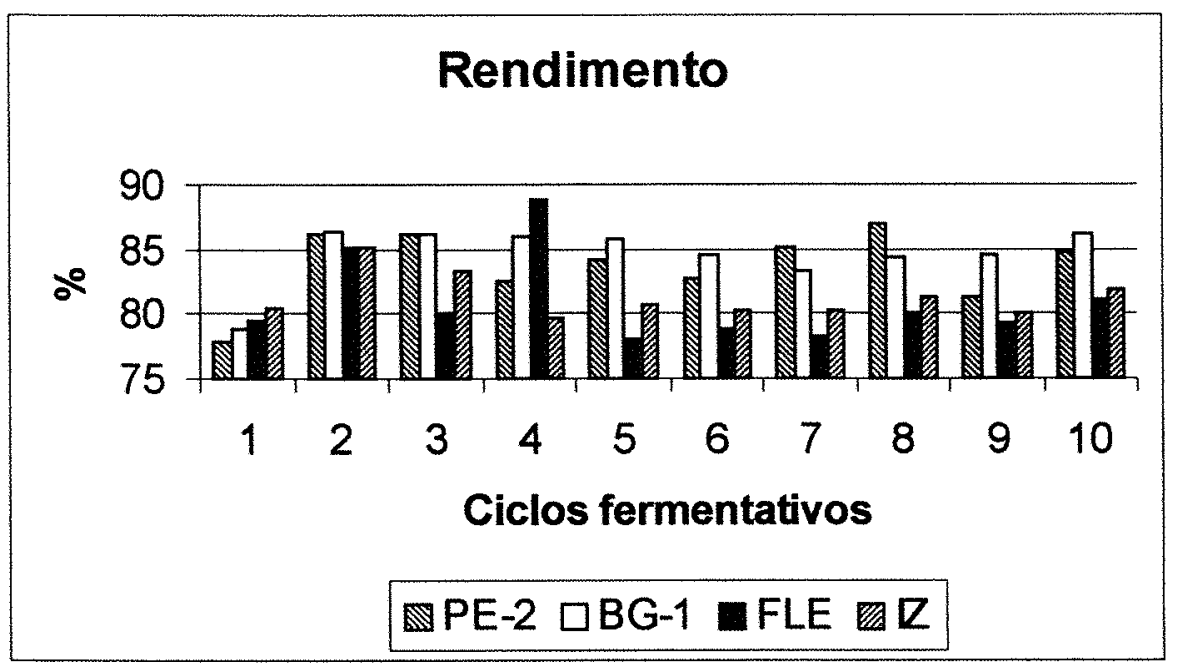

Figura 7 - Efeito de diferentes leveduras em co-cultura com lactobacilos ao longo de 10 ciclos fermentativos sobre o parâmetro rendimento.

Teste de Tukey para médias de tratamento e ciclo.

\begin{tabular}{cccc}
\hline Tratamento & Média & $5 \%$ & $1 \%$ \\
\hline BG-1 & 84,56 & a & A \\
PE-2 & 83,76 & a & A \\
IZ & 81,29 & ab & A \\
FLE & 79,89 & b & A \\
\hline
\end{tabular}

Médias seguidas por letras distintas diferem entre si ao nivel de significância indicado.

C.V. $=0,813 \%$

D.M.S. $5 \%=3,66914$

D.M.S. $1 \%=5,26410$

\begin{tabular}{cccc}
\hline Ciclo & Média & $5 \%$ & $1 \%$ \\
\hline 2 & 85,69 & $\mathrm{a}$ & $\mathrm{A}$ \\
3 & 83,90 & ab & $\mathrm{AB}$ \\
10 & 83,52 & $\mathrm{bc}$ & $\mathrm{ABC}$ \\
8 & 83,13 & bcd & $\mathrm{BC}$ \\
5 & 82,11 & bcd & $\mathrm{BC}$ \\
4 & 81,73 & $\mathrm{~cd}$ & $\mathrm{BC}$ \\
7 & 81,70 & $\mathrm{~cd}$ & $\mathrm{BC}$ \\
6 & 81,58 & $\mathrm{~cd}$ & $\mathrm{BCD}$ \\
9 & 81,26 & $\mathrm{~d}$ & $\mathrm{CD}$ \\
1 & 79,13 & $\mathrm{e}$ & $\mathrm{D}$ \\
\hline
\end{tabular}

Médias seguidas por letras distintas diferem entre si ao nivel de significância indicado.

C.V. $=1,931 \%$

D.M.S. $5 \%=2,12308$

D.M.S. $1 \%=2,48220$ 